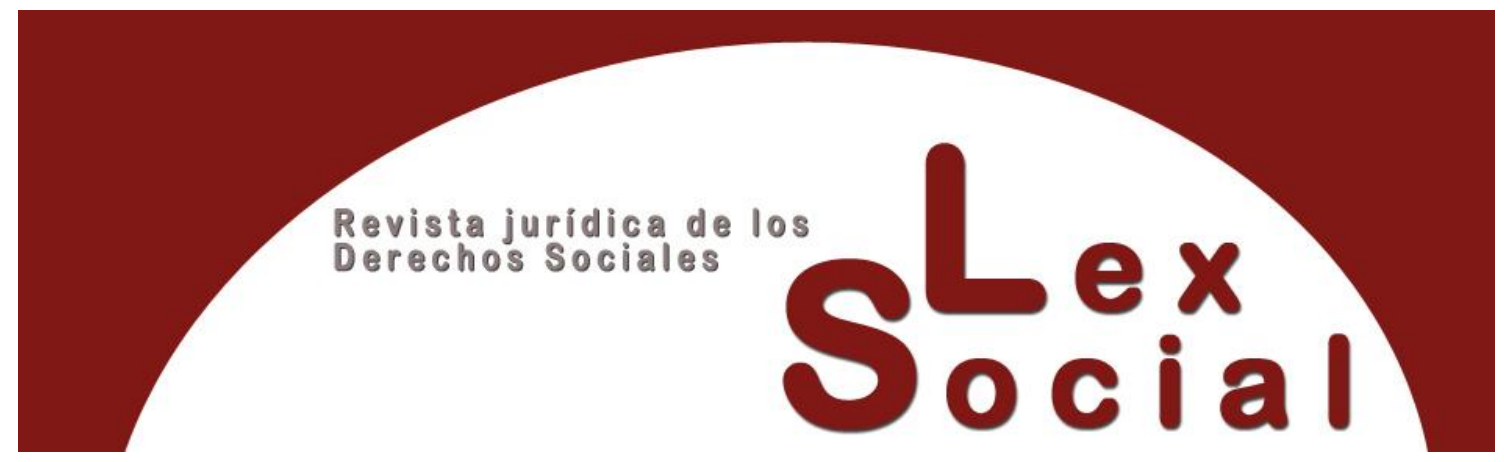

\title{
LA CONTROVERTIDA INDEMNIZACIÓN POR LESIÓN DE LOS DERECHOS FUNDAMENTALES DE LAS PERSONAS TRABAJADORAS
}

\section{THE CONTROVERTED INDEMNITY FOR INJURY OF THE FUNDAMENTAL RIGHTS OF WORKERS}

EVA LÓPEZ TERRADA

\author{
Profesora Titular de Derecho del Trabajo y de la Seguridad Social \\ Universitat de València \\ https://orcid.org/0000-0002-7702-2393
}

Cómo citar este trabajo: López Terrada, E. (2021). La controvertida indemnización por lesión de los derechos fundamentales de las personas trabajadoras. Lex Social: Revista De Derechos Sociales, 11(1), 2-39. https://doi.org/10.46661/lexsocial.5412

\begin{abstract}
RESUMEN
El reconocimiento y cuantificación de las indemnizaciones por vulneración de derechos fundamentales en el orden social de la jurisdicción ha sido, desde siempre, y por diferentes razones, una cuestión especialmente compleja. En ciertos casos como sucede con la automaticidad del daño moral derivado de la violación del derecho fundamental- las contradicciones y vaivenes judiciales son ya un "clásico" en la materia; en otros, las dudas guardan relación con el significado y la repercusión que una incorporación legal efectuada por la LRJS -la finalidad preventiva de la indemnización- debe tener en la práctica judicial; y, finalmente, las discrepancias se refieren a la posibilidad misma de concesión de la indemnización en determinadas situaciones -nulidades "objetivas" o "automáticas" de los despidos por aplicación del artículo 55.5 del Estatuto de los Trabajadores-.
\end{abstract}

Palabras Clave: Indemnización, derechos fundamentales, daños morales, daños punitivos, despidos nulos. 


\begin{abstract}
Since always, and for different reasons, recognizing and quantifying compensation for infringement of fundamental rights in the social order of the jurisdiction has been a very complex issue. In some cases, as it happens with the automaticity of the moral damages resulting from the violation of the fundamental right - the contradictions and judicial swings are a "classic" in the matter. In other cases, the doubts are related to the meaning and repercussion that a legal incorporation carried out by the LRJS - the preventive purpose of compensation - should have on judicial practice. Finally, the discrepancies are related to the very possibility of granting compensation in certain situations, such as "objective" or "automatic" annulments of dismissals by application of article 55.5 of the Workers' Statute.
\end{abstract}

KEYWORDS: Compensation, fundamental rights, moral damages, punitive damages, null dismissals.

\title{
SUMARIO
}

\section{Introducción}

II. La protección jurisdiccional de los derechos y libertades fundamentales en el ámbito de las relaciones de trabajo

1. La tardía y limitada aparición de una modalidad procesal específica

2. El problema de los reenvíos a otras modalidades procesales

III. La reparación del daño moral derivado de la vulneración de derechos fundamentales

1. La automaticidad de la indemnización por daños morales: etapas

1.1. Los primeros vaivenes interpretativos

1.2. La sentencia del Tribunal Constitucional 247/2006, de 24 de julio

1.3. La deriva hacia el carácter automático de la indemnización

1.4. La automaticidad de la indemnización tras la LRJS

2. La cuantificación y fiscalización del importe indemnizatorio

2.1. La consideración de los factores concurrentes en la determinación de la indemnización

2.2. La justificación del concreto importe indemnizatorio fijado por analogía con la LISOS

IV. La finalidad preventiva de la indemnización por vulneración de derechos fundamentales

1. El debate sobre la equivalencia entre la función preventiva y el carácter punitivo de la indemnización

1.1. La discutida figura de los daños punitivos

\section{(c) BY-NC-SA}


1.2. La integración de los daños punitivos en la Ley Reguladora de la Jurisdicción social

2. La recepción judicial de la nueva función de prevención general asignada a la indemnización

$V$. La indemnización por vulneración de derechos fundamentales en caso de nulidad "objetiva" del despido

VI. Conclusiones

Bibliografía

\section{Introducción}

Según dispone la Exposición de Motivos de la Ley 36/2011, de 10 de octubre, reguladora de la jurisdicción social (en adelante, LRJS), las disposiciones contenidas en sus artículos 177 a 184 disciplinan el proceso de tutela de los derechos fundamentales y libertades públicas "ajustándolo a la doctrina constitucional, con una regulación más completa y estructurada (...), particularmente en cuanto a los términos de los pronunciamientos a dictar y respecto del resarcimiento de la víctima...".

A este respecto es necesario recordar, como punto de partida, que el artículo 183 LRJS establece, en su apartado primero, que, cuando la sentencia recaída en los procesos de tutela de los derechos fundamentales y libertades públicas declare la existencia de vulneración, el juez deberá pronunciarse sobre "la cuantía de la indemnización que, en su caso, le corresponda a la parte demandante por haber sufrido discriminación u otra lesión de sus derechos fundamentales y libertades públicas, en función tanto del daño moral unido a la vulneración del derecho fundamental, como de los daños y perjuicios adicionales derivados". Añade el apartado segundo del mismo precepto que el tribunal se pronunciará "sobre la cuantía del daño, determinándolo prudencialmente cuando la prueba de su importe exacto resulte demasiado difícil o costosa, para resarcir suficientemente a la víctima y restablecer a ésta, en la medida de lo posible, en la integridad de su situación anterior a la lesión, así como para contribuir a la finalidad de prevenir el daño".

Lo cierto es que el reconocimiento y cuantificación de las indemnizaciones por vulneración de derechos fundamentales en el orden social de la jurisdicción ha sido, desde siempre, y por diferentes razones, una cuestión especialmente compleja.

Históricamente, ello fue consecuencia, sin duda alguna, de la tardía y limitada aparición de una modalidad específicamente dedicada a la protección jurisdiccional de los derechos laborales de carácter fundamental y, desde luego, según se verá, de su concepción como una modalidad procesal de carácter "residual" (II). 
Pero, en la actualidad, la oscuridad del tema $-\mathrm{y}$ la incuestionable conveniencia de su examen detenido- procede, fundamentalmente, de las constantes controversias interpretativas que han tenido lugar en sede judicial desde la aparición misma de esta específica modalidad de tutela de los derechos fundamentales y las libertades públicas.

Como se analiza en el presente estudio, las contradicciones y vaivenes judiciales comenzaron, efectivamente, con la entrada en vigor de la Ley de Procedimiento Laboral de 1990 (en adelante, LPL), ante la falta de acuerdo acerca de la automaticidad del daño moral derivado de la violación del derecho fundamental y la consiguiente obligación de decretar la indemnización correspondiente al mismo (III.1). Por si ello fuera poco, la inexistencia de normas aplicables a la cuantificación de dicho importe indemnizatorio y su posible fiscalización por parte de los tribunales superiores han derivado en una intensa labor interpretativa por parte de los tribunales del orden social que se encontraba, igualmente, necesitada de estudio (III.2).

Con el tiempo, las dudas y enfrentamientos interpretativos se han relacionado, a pesar de la intención declarada en su Exposición de Motivos, con el significado y la repercusión que una incorporación legal efectuada por la LRJS, como es la finalidad preventiva de la indemnización, debe tener en la práctica judicial. Por un lado, resulta incierto si la introducción de tal finalidad preventiva ha supuesto, también, la recepción de los llamados "daños punitivos" en la ordenación de esta figura (IV.1). Por otro lado, queda por resolver el modo en que la finalidad preventiva debe quedar reflejada a la hora de especificar la cuantía de la indemnización (IV.2).

Finalmente, las discrepancias se están refiriendo a la posibilidad misma de concesión de la indemnización en determinadas situaciones (V). Existe, ciertamente, un enfrentamiento en la doctrina de suplicación, que urge resolver, relativo al reconocimiento de la indemnización en los supuestos de las llamadas nulidades "objetivas" o "automáticas" de los despidos reguladas por el artículo 55.5 del Estatuto de los Trabajadores (en adelante, ET).

\section{La protección jurisdiccional de los derechos y libertades fundamentales en el ámbito de las relaciones de trabajo}

La crónica de la tutela de los derechos fundamentales y libertades públicas por parte de los órganos judiciales integrantes del orden social se encuentra jalonada, desde su inicio, por dificultades de alcance muy diverso. Entre ellas es posible destacar, sin embargo, las más directamente relacionadas con la consecución de la tutela que el artículo 53.2 de la Constitución Española (en adelante, CE) proclama: “Cualquier ciudadano podrá recabar la tutela de las libertades y derechos reconocidos en el artículo 14 y la Sección primera del Capítulo segundo ante los Tribunales ordinarios por un procedimiento basado en los principios de preferencia y sumariedad". 
Desde esta perspectiva, merecen ser recordadas, siquiera brevemente, las vicisitudes relacionadas con el propio reconocimiento legal de un proceso especial en la materia, pues tal reconocimiento, además de tardío, se centró en principio casi de forma exclusiva en el derecho de libertad sindical. Además, resulta preciso destacar los inconvenientes que derivaron de la configuración de tal proceso especial como una modalidad procesal de carácter aparentemente residual como consecuencia de los reenvíos obligatorios efectuados a otras modalidades procesales especiales.

\section{La tardía y limitada aparición de una modalidad procesal específica}

Es, en efecto, llamativo que, a pesar de la contundente literalidad del artículo 53.2 CE, la aparición de un proceso especial de tutela de los derechos fundamentales y libertades públicas ante los órganos jurisdiccionales del orden social no se produjera hasta la entrada en vigor de la LPL de 1990.

En principio, la Ley 62/1978, de 26 de diciembre, de Protección Jurisdiccional de los Derechos Fundamentales de la Persona, únicamente regulaba las libertades de expresión, reunión y asociación, la libertad y secreto de la correspondencia, la libertad religiosa y la de residencia, la garantía de la inviolabilidad del domicilio, la protección jurídica frente a las detenciones ilegales y, en general, frente a las sanciones impuestas en materia de orden público ( $c f r$. su artículo 1.2). El motivo de esta limitación hay que buscarlo, probablemente, en los orígenes de la norma, los Pactos de la Moncloa de 1977, que se referían de forma expresa, como consecuencia lógica del momento histórico atravesado, al impulso de la regulación de determinados derechos de claro contenido político como los derechos de reunión y asociación política, o la revisión de sanciones en materia de orden público ${ }^{1}$. Con todo, la disposición final de dicha ley preveía que dentro de los dos meses siguientes a la entrada en vigor de la CE el Gobierno podría incorporar a su ámbito de protección "los nuevos derechos constitucionalmente declarados que sean susceptibles de ella".

El problema fue que el Real Decreto 342/1979, de 20 de febrero, legislativo sobre ampliación del ámbito de la Ley 62/1978, de 26 de diciembre, únicamente incorporó los derechos al honor, a la intimidad personal y familiar y a la propia imagen, el secreto de las comunicaciones telefónicas y telegráficas, la libre circulación por el territorio nacional, la libre entrada y salida de España en los términos legales, la libertad de cátedra y la libertad sindical, obviando cualquier referencia, por ejemplo, al derecho de huelga. Fue necesario esperar, por ello, a que la Ley Orgánica 2/1979, de 3 de octubre, del Tribunal Constitucional, extendiera el ámbito de la Ley 62/1978 a todos los derechos fundamentales y libertades públicas, en consonancia con lo prescrito por el artículo 53.2 CE (vid. disposición transitoria segunda, dos, de la Ley Orgánica 2/1979).

\footnotetext{
${ }^{1}$ MANEIRO VÁZQUEZ, Yolanda, La tutela de los derechos fundamentales y libertades públicas por los tribunales laborales, La Coruña, Netbiblo, 2007, p. 2-3. 
La Ley 62/1978 no incluyó, sin embargo, una vía específicamente laboral para la protección de estos derechos, sino que se limitó a regular las garantías penales, contencioso-administrativas y civiles. A juicio de la doctrina ello, si bien podía suponer ciertas ventajas respecto a los procesos penal, administrativo y civil ordinarios, resultaba criticable desde el punto de vista del proceso laboral ordinario, caracterizado por ser rápido, gratuito y sin exigencias de postulación y, además, exigía que tribunales ajenos al orden social de la jurisdicción conociesen de cuestiones laborales ${ }^{2}$.

Ante el estado de anomia legislativa existente -motivada también por el silencio de la LPL de 1980- se impuso la intervención del Tribunal Constitucional, que se vio obligado a precisar que "es doctrina de este Tribunal que el cauce natural de dicha protección en la jurisdicción ordinaria es el procedimiento laboral. Con esta acción integradora con respecto a la (...) Ley 62/1978, el proceso laboral se convierte también en proceso de protección jurisdiccional de los derechos laborales de carácter fundamental" (SSTC 55/1983, de 22 de junio; 47/1985, de 27 de marzo; 6/1988, de 21 de enero, o 51/1988, de 22 de marzo).

Cuando el reconocimiento legal, por fin, se produjo, y aun sin ser imposible la tutela de otros derechos fundamentales y libertades públicas, la especial atención otorgada a la libertad sindical se hizo evidente. De entrada, en la Base Trigésima de la Ley 7/1989, de 12 de abril, de Bases de Procedimiento Laboral, que la ley de 1990 vino a desarrollar, se mencionaba de forma exclusiva el proceso de protección jurisdiccional de los derechos fundamentales de la persona a que se refiere el artículo 13 de la Ley Orgánica 11/1985, de 2 de agosto, de Libertad Sindical. Además, los artículos 174 a 181 de la LPL de 1990 (artículos 175 a 182 tras la refundición de 1995) regulaban la modalidad procesal "de tutela de los derechos de libertad sindical": fue necesario esperar a la reforma operada por la Ley 13/2009, de 3 de noviembre, para que el procedimiento pasara a denominarse de tutela de los derechos fundamentales. Pero, incluso entonces, la literalidad legal estaba enfocada, de manera preferente, en la vulneración del derecho de libertad sindical, hasta el punto que resultaba necesario aclarar que "las demandas de tutela de los demás derechos fundamentales y libertades públicas, incluida la prohibición de tratamiento discriminatorio, que se susciten en el ámbito de las relaciones jurídicas atribuidas al conocimiento del orden jurisdiccional social, se tramitarán conforme a las disposiciones establecidas en este capítulo" (artículo 180 LPL de 1990; artículo 181 tras la refundición de 1995).

La situación no podía ser ignorada, en fin, por la reforma llevada a cabo por parte de la LRJS, cuyo Preámbulo reconoce expresamente que la nueva regulación del proceso de

\footnotetext{
${ }^{2}$ LOUSADA AROCHENA, José Fernando, La tutela de los derechos fundamentales y de las libertades públicas en la Ley Reguladora de la Jurisdicción Social, Albacete, Bomarzo, 2012, p. 13; MONTOYA MELGAR, Alfredo, et al., Curso de procedimiento laboral, Madrid, Tecnos, 2012, $9^{\text {a }}$ ed., p. 289-290; MANEIRO VÁZQUEZ, Yolanda, La tutela de los derechos fundamentales y libertades públicas por los tribunales laborales, La Coruña, Netbiblo, 2007, p. 5.
} 
tutela de los derechos fundamentales y libertades públicas expande el ámbito de la modalidad procesal "de modo decidido" más allá de "la invocación principal de derechos fundamentales laborales específicos, como la libertad sindical", para comprender con amplitud toda posible vulneración de tales derechos y libertades fundamentales en el ámbito de las relaciones de trabajo "sean genéricos o específicamente laborales".

\section{El problema de los reenvíos a otras modalidades procesales}

La segunda gran dificultad que ha tenido que superarse en el proceso de tutela que se analiza desde el punto de vista de su ajuste al mandato constitucional del artículo 53.2 CE guarda relación con la remisión efectuada por el artículo 181 de la LPL de 1990 (artículo 182 del texto refundido de 1995) a otras modalidades especiales ${ }^{3}$. El problema de encaje era evidente: puesto que las modalidades procesales especiales a las que el precepto obligatoriamente reenviaba carecían de las garantías de preferencia y sumariedad que la Constitución impone, quedaba desnaturalizada la protección excepcional pretendida por el artículo 53.2 CE.

Frente a esta aparente privación de derechos a la que conducía la literalidad de la ley, un sector de la doctrina científica ideó una vía de solución, al interpretar que el artículo 181 LPL -luego 182- tenía la virtualidad de integrar las especialidades que presiden la tramitación del proceso de tutela de derechos fundamentales en las respectivas modalidades procesales. De esa manera, se entendía que, cuando la tutela de los derechos fundamentales y libertades públicas se produjera en conexión con las situaciones determinantes de los procesos a los que se reenviaba, la tramitación específica con arreglo a las correspondientes modalidades procesales no significaba la inaplicación del conjunto de principios y garantías que informaban -e informan- el proceso laboral de amparo ordinario $^{4}$. Esta postura hermenéutica, aunque se acogió expresamente por parte de la doctrina de suplicación ${ }^{5}$, no fue del todo unánime. Contrariamente, las dudas interpretativas en torno a la aplicación de las garantías del proceso de tutela de la libertad

\footnotetext{
3 “Las demandas por despido y por las demás causas de extinción del contrato de trabajo, las de disfrute de vacaciones, las de materia electoral, las de impugnación de Estatutos de los Sindicatos o de su modificación y las de impugnación de Convenios Colectivos en que se invoque lesión de la libertad sindical u otro derecho fundamental se tramitarán, inexcusablemente, con arreglo a la modalidad procesal correspondiente"

4 Vid., ampliamente, por todos, PEDRAJAS MORENO, Abdón., Despido y derechos fundamentales. Estudio especial de la presunción de inocencia, Madrid, Trotta, 1992, p. 131 y ss.; o BLASCO PELLICER, Ángel y LÓPEZ TERRADA, Eva, "Proceso de tutela de los derechos fundamentales y libertades públicas", en: BLASCO, Ángel; ALEGRE, Manuel (coords.), El proceso laboral: Ley 36/2011, de 10 de octubre, reguladora de la Jurisdicción Social, Valencia, Tirant lo Blanch, 2013, pp. 1103 y ss. y la doctrina que allí se cita.

${ }^{5}$ STSJ de Madrid de 18 de junio de 1991, a la que siguieron otras, como la del mismo Tribunal de 31 de julio de 1992 (Rec. 366/1992) o la del TSJ de Castilla-La Mancha de 25 de octubre de 1993 (Rec. 756/1993).
} 
sindical en los supuestos de reenvío generaron discusiones $\mathrm{y}$, por consiguiente, debilitación de la tutela ${ }^{6}$.

Sea como fuere, la tesis mencionada quedó reflejada con posterioridad, aunque de forma indirecta, en el Auto del TC 311/1999, de 14 de diciembre, y, finalmente, la tesis de la integración se admitió por el propio Tribunal Supremo, en su sentencia de 12 de junio de 2001 (Rec. 3827/2000), en la que el Tribunal debía pronunciarse sobre la posibilidad de adicionar en una causa por despido, en la que había recaído sentencia declarando la nulidad del realizado, por violación de derechos fundamentales del trabajador, la indemnización por tal agresión: “...siendo así que los derechos fundamentales y libertades a que nos estamos refiriendo no pueden quedar sin un procedimiento "preferente y sumario" para su tutela, ha de concluirse que el proceso por despido es el idóneo para decidir sobre estos extremos, debiendo entenderse desplazado el mandato del art. 27.2 de la Ley Procesal por el del art. 182. Entenderlo de otro modo obligaría al trabajador afectado a emprender un proceso distinto, que -no siendo el de despido- habría de ser el ordinario, que no reúne los requisitos constitucionalmente exigidos...".

Aunque gracias a las reformas introducidas por la Ley Orgánica 3/2007, de 22 de marzo, para la igualdad efectiva de mujeres y hombres, la compatibilidad entre las consecuencias legales de un despido nulo y la indemnización derivada de discriminación o lesión de derechos fundamentales se admitió expresamente por la ley (arts. 27.2 -27.4 tras la reforma de la Ley 13/2009-180.1 y 182 de la LPL), fue, sin duda, la entrada en vigor de la LRJS la que consolidó de forma definitiva el proceso. Así, a día de hoy, la literalidad del artículo 184 LRJS exige que las demandas por despido y por las demás causas de extinción del contrato de trabajo, las de modificaciones sustanciales de condiciones de trabajo, las de suspensión del contrato y reducción de jornada por causas económicas, técnicas, organizativas o de producción o derivadas de fuerza mayor, las de disfrute de vacaciones, las de materia electoral, las de impugnación de estatutos de los sindicatos o de su modificación, las de movilidad geográfica, las de derechos de conciliación de la vida personal, familiar y laboral a las que se refiere el artículo 139, las de impugnación de convenios colectivos y las de sanciones impuestas por los empresarios a los trabajadores en que se invoque lesión de derechos fundamentales y libertades públicas, se tramiten "inexcusablemente" con arreglo a la modalidad procesal correspondiente a cada una de ellas.

Ahora bien, esta exigencia se acompaña, por un lado, de la obligación de dar carácter preferente a dichos procesos y acumular en ellos, según lo dispuesto en artículo 26.2, las pretensiones de tutela de derechos fundamentales y libertades públicas con las propias de la modalidad procesal respectiva. El mencionado artículo 26.2 de la LRJS permite, en

\footnotetext{
${ }^{6}$ LOUSADA AROCHENA, José Fernando, La tutela de los derechos fundamentales y de las libertades públicas en la Ley Reguladora de la Jurisdicción Social, Albacete, Bomarzo, 2012, pp. 14-15, de nuevo con amplia cita de la doctrina científica estudiosa del tema.
} 
efecto, reclamar, cuando la tutela del derecho deba necesariamente realizarse a través de las "otras" modalidades procesales, en virtud de lo establecido en el actual artículo 184, la indemnización derivada de discriminación o lesión de derechos fundamentales y libertades públicas y demás pronunciamientos propios de la modalidad procesal de tutela de tales derechos fundamentales y libertades públicas.

Además, la exigencia del artículo 184 se declara, por otro lado, "sin perjuicio de lo dispuesto en el apartado 2 del artículo 178", precepto que ha pasado a reconocer con carácter general en estos casos de tramitación obligatoria por otras modalidades procesales la aplicación en cuanto a las pretensiones de tutela de derechos fundamentales y libertades públicas de "las reglas y garantías previstas en este Capítulo, incluida la citación como parte al Ministerio Fiscal”.

\section{La reparación del daño moral derivado de la vulneración de derechos fundamentales}

La lesión de un derecho fundamental determina normalmente -según recordara el Tribunal Supremo al referirse a la indemnización por vulneración de derechos fundamentales (vid., por todas, STS de 12 de diciembre de 2007, Rec. 25/2017)- la producción de un daño, en la medida en que esa lesión se proyecta lógicamente sobre un bien ajeno. De ahí que, desde la aparición del proceso especial en el orden social, forme parte del contenido de la sentencia estimatoria de la demanda de tutela de un derecho fundamental "la reparación de las consecuencias derivadas del acto, incluida la indemnización que procediera" ( $c f r$. artículo 180 LPL). Y es que no cabe olvidar que la CE protege los derechos fundamentales, no en sentido teórico e ideal, sino como derechos reales y específicos, y que los artículos 9.1, 1.1. y 53.2 CE impiden que la protección jurisdiccional de los derechos y libertades se conviertan en un "acto meramente ritual o simbólico" (por todas, SSTC 176/1988, de 4 de octubre y 12/1994, de 17 de enero).

Pese a que este punto de partida ofrece poco margen de discusión, la necesidad de incluir en la reparación del daño la compensación del daño moral ha resultado ser una cuestión especialmente conflictiva, tanto por lo que a la concesión misma de la indemnización compensatoria del daño moral se refiere, como por lo que respecta a la cuantificación de la indemnización. Se trata, pues, de una materia en la que, como ha reconocido el propio Tribunal Supremo, la interpretación de los tribunales no ha tenido, desde luego, "la uniformidad que sería deseable" (por todas, STS de 19 de diciembre de 2017, Rec. 624/2016). 


\section{La automaticidad de la indemnización por daños morales: etapas}

\subsection{Los primeros vaivenes interpretativos}

A los efectos que aquí interesa, y sin pretensión alguna de analizar el "enormemente difícil concepto" de daño moral ${ }^{7}$, cabe destacar, simplemente, que, en su integración negativa, la jurisprudencia entiende por daño moral toda aquella detracción que sufre el perjudicado damnificado que, por naturaleza, no cabe incluir, en los daños materiales "porque estos son aprehensibles por su propia caracterización", y que tampoco cabe enmarcar dentro de la categoría de los daños corporales "porque estos, por su propio carácter, son perfectamente sensibles" (STS, Sala 1a , de 22 de febrero de 2001, Rec. 358/1996). En su integración positiva, la doctrina jurisprudencial acepta la identificación del daño moral con "el impacto o sufrimiento psíquico o espiritual" que en la persona pueden producir ciertas conductas, actividades o, incluso, resultados, tanto si implican una agresión directa o inmediata a bienes materiales, como si el ataque afecta al acervo extrapatrimonial o de la personalidad. De ahí que, ante, frente o junto a la obligación de resarcir que surge de los daños patrimoniales, traducido en el resarcimiento económico o dinerario del lucro censans y/o del damnum emergens, se haya arbitrado y dado carta de naturaleza en nuestro derecho a la reparación del daño o sufrimiento moral, "que si bien no atiende a la reintegración de un patrimonio, va dirigida, principalmente, a proporcionar en la medida de lo humanamente posible una satisfacción como compensación al sufrimiento que se ha causado" (por todas, STS, Sala 1ª de 25 de junio de 1984). El daño moral es así, en definitiva, a juicio del Tribunal Supremo, el infringido a la dignidad, a la estima moral y cabe en las personas jurídicas (STS, Sala 1ª de 20 de febrero de 2002, Rec. 2855/1996).

Pues bien, en el orden social, desde la aparición misma de la modalidad procesal de tutela de los derechos de libertad sindical y otros derechos fundamentales en la Ley de Procedimiento Laboral de 1990, la doctrina de suplicación quedó divida en dos bloques claramente diferenciados por lo que a la concesión de la indemnización compensatoria del daño moral se refiere ${ }^{8}$. El primero entendía que, una vez declarada por el juez la producción de la violación del derecho fundamental, procedía decretar la reparación consiguiente de las consecuencias ilícitas de la violación, incluida la indemnización que procediera (STSJ de Cataluña de 15 de marzo de 1993, por todas). Mientras, el segundo bloque interpretaba, por el contrario, que era preciso que el sujeto víctima de la lesión probase que se le había producido un perjuicio para que naciese el derecho a la indemnización del daño moral. Se afirmaba, en este sentido, que, al no prever la LPL necesariamente una indemnización, esta sólo podía descansar en la demostración de la realidad de los daños y perjuicios ocasionados de modo directo por la conducta lesiva;

\footnotetext{
${ }^{7}$ DÍEZ-PICAZO, Luis, El escándalo del daño moral, Cizur Menor, Thomson-Civitas, 2008, p. 13.

8 Ampliamente, BLASCO PELLICER, Ángel y LÓPEZ TERRADA, Eva, "Proceso de tutela de los derechos fundamentales y libertades públicas", en: BLASCO PELLICER, Ángel; ALEGRE NUENO, Manuel (coords.), El proceso laboral: Ley 36/2011, de 10 de octubre, reguladora de la Jurisdicción Social, Valencia, Tirant lo Blanch, 2013, pp. 1138 y ss.
} 
por lo que, de no existir tal demostración, debía declararse plenamente satisfecho el daño moral con el éxito de la demanda sin que procediese reconocer indemnización alguna (vid., entre otras, SSTSJ de Andalucía -Sevilla- de 16 de diciembre de 1992, Rec. 2755/1992; o de 28 de julio de 1993, Rec. 1259/1993).

En una etapa inicial, el Tribunal Supremo unificó doctrina optando por el criterio de la "automaticidad del daño", en virtud del cual declarada la violación del derecho fundamental se presume la existencia del daño moral y nace el derecho a la indemnización del mismo: "debe entenderse que no es necesario probar que se ha producido un perjuicio para que nazca el derecho al resarcimiento sino que, por el contrario, una vez acreditada la vulneración del derecho fundamental se presume la existencia del daño y debe decretarse la indemnización correspondiente" (STS de 9 de junio de 1993, Rec. 3853/1992, cuya doctrina reitera la STS de 8 de mayo de 1995, Rec. 1319/1994).

Sin embargo, esta posición hermenéutica quedó rectificada con rapidez en sentencias posteriores que negaban expresamente el carácter automático de la tutela “... la sentencia de esta Sala de 9 de junio de 1993 no puede ser entendida en el sentido de que el demandante en estos especiales procesos queda totalmente exento de la obligación de alegar y razonar en su demanda los fundamentos de su pretensión indemnizatoria, ni que tampoco esté obligado a acreditar una mínima base fáctica que sirva para delimitar los perfiles y elementos de la indemnización que se haya de aplicar; antes al contrario, lo que se declara en esa sentencia es perfectamente compatible con la necesidad de que dicho demandante, para que su petición indemnizatoria pueda ser estimada, tenga que cumplir las exigencias que se acaban de mencionar" (STS de 22 de julio de 1996, Rec. 3780/1995, cuya rectificación confirma la posterior de 30 de enero de 1997, Rec. 1642/1996) ${ }^{9}$. Así, desde esta perspectiva, de lo dispuesto en los artículos 15 de la Ley Orgánica de la Libertad Sindical (en adelante, LOLS) y 180.1 de la LPL - que precisaba, según se dijo, que la sentencia que declarase la existencia de la vulneración del derecho había de disponer "la reparación de las consecuencias derivadas del acto, incluida la indemnización que procediera"- se deducía que para poder adoptar el mencionado pronunciamiento condenatorio era de todo punto obligado que, en primer lugar, el demandante alegase adecuadamente en su demanda "las bases y elementos clave de la indemnización" que reclamaba, que justificasen suficientemente que la misma correspondía ser aplicada al supuesto concreto de que se tratase, y dando las pertinentes razones que avalasen y respaldasen dicha decisión; y, en segundo lugar, que quedasen acreditados, cuando menos, "indicios o puntos de apoyo suficientes" en los que se pudiera asentar una condena de tal clase.

\footnotetext{
${ }^{9}$ Al respecto, por todos, CARDENAL CARRO, Miguel, La indemnización en los procesos de tutela de la libertad sindical (Un estudio jurisprudencial del razonamiento acerca de su pertinencia), Pamplona, Thomson-Aranzadi, 2006, pp. 39 y ss.
} 
La doctrina imperante en esta segunda etapa tendió, con carácter general, a un endurecimiento progresivo, pues pasó a vincularse el reconocimiento de la indemnización a la existencia de datos probatorios no solo del posible daño, sino también de los parámetros identificadores de su cuantía. De este modo, también se negaba el derecho a indemnización cuando "no hay dato alguno que facilite las pautas para cuantificar el importe del daño a reparar" ( $c f r$. SSTS de 2 de febrero de 1998, Rec. 1725/1997; de 28 de febrero de 2000, Rec. 2346/2000; de 17 de enero de 2003, Rec. 3650/2001, y de 21 de julio de 2003, Rec. 4409/2002). Su evolución no fue, con todo, absolutamente lineal ${ }^{10}$; de hecho, cabe identificar algún pronunciamiento posterior más cercano a la tesis de la automaticidad que, en realidad, no había desaparecido del todo de la doctrina de suplicación ( $c f r$. STSJ del País Vasco de 14 de mayo de 2002, Rec. 933/2002).

\subsection{La sentencia del Tribunal Constitucional 247/2006, de 24 de julio}

En todo caso, en una tercera etapa, esta doctrina fue precisada, aunque sin llegar a ser sustituida por considerarse "irreprochable" desde la perspectiva constitucional, por la STC 247/2006, de 24 de julio.

La sentencia resolvió un recurso de amparo planteado por un profesor de religión y moral católica que, como representante legal de los trabajadores, había iniciado actuaciones contra la Consejería de Educación, Cultura y Deportes del Gobierno de la Comunidad Autónoma de Canarias por cuenta de la cual trabajaba, tendentes a la regularización del colectivo de profesores de religión, que incluyeron la promoción de una huelga de cuyo comité formó parte. Como consecuencia de ello, había sufrido, según describía en su demanda de tutela de la libertad sindical, conductas antisindicales consistentes en la prohibición por parte de la Consejería empleadora de su asistencia a las reuniones del comité de empresa al que pertenecía, su traslado sin causa a un nuevo puesto de trabajo, así como la reducción injustificada de su jornada de trabajo y la consiguiente reducción de su salario. Tales conductas le habían ocasionado, como alegaba en su demanda, daños económicos, morales y de toda índole que debían ser reparados, a cuyo efecto, teniendo en cuenta el carácter reincidente de la conducta empresarial, y tomando como referencia lo previsto en el Real Decreto Legislativo 5/2000, de 4 de agosto, por el que se aprueba el texto refundido de la Ley sobre infracciones y sanciones en el orden social (en adelante, LISOS), solicitaba una indemnización de diez millones de pesetas.

En principio, la Sentencia de 31 de julio de 2001 del Juzgado de lo Social núm. 5 de Las Palmas de Gran Canaria le reconoció una indemnización de cinco millones de pesetas, en lugar de los diez millones de pesetas solicitados. Por su parte, la Sentencia de 26 de julio de 2002 de la Sala de lo Social del TSJ de Canarias (Las Palmas), desestimó el recurso

\footnotetext{
${ }^{10}$ LAHERA FORTEZA, Jesús, "Las acciones de indemnización de daños por vulneración de la libertad sindical tras la Ley 36/2011 de Jurisdicción Social”, Relaciones Laborales, 8, 2012, p. 32; MANEIRO VÁZQUEZ, Yolanda, "El derecho a la indemnización por daños morales como consecuencia de la lesión de la libertad sindical a la luz de la sentencia TC 247/2006, de 24 de julio", Dereito: revista xurídica da Universidade de Santiago de Compostela, Vol.22, no ext.:245-263, 2013, pp. 253-254.
} 
de suplicación interpuesto por la Consejería condenada contra la Sentencia anterior, tras afirmar que no era necesario probar que se hubiera producido un perjuicio para que naciera el derecho al resarcimiento sino que, por el contrario, una vez acreditada la vulneración del derecho fundamental se presumía la existencia del daño y debía decretarse la indemnización correspondiente. Citaba para ello la doctrina inicialmente establecida por el Tribunal Supremo sobre la automaticidad del daño moral en su sentencia de 9 de junio de 1993. Por fin, la STS de 21 de julio de 2003 (Rec. 4409/2002), que es contra la que se dirige el recurso, decidió dejar sin efecto el reconocimiento de la indemnización por daños y perjuicios acordada por las sentencias de instancia y suplicación. Para resolver el debate doctrinal planteado en la casación unificadora, la Sala estimó que la doctrina correcta en orden a la aplicación del artículo 180.1 LPL era la recogida en su sentencia de 28 de febrero de 2000 (Rec. 2346/2000) que, como se indicó, se inscribe en la línea "dura" de la segunda etapa descrita, caracterizada por vincular el reconocimiento de la indemnización a la existencia de datos probatorios no solo del posible daño, sino también de los parámetros identificadores de su cuantía.

La motivación de la STS de 28 de febrero de 2000 es analizada por el Tribunal Constitucional desde la perspectiva del derecho a la tutela judicial efectiva que el artículo 24.1 CE consagra. Como no podía ser de otra forma, el Tribunal Constitucional comienza su razonamiento reconociendo el cambio que había tenido lugar en la doctrina de la Sala de lo Social del Tribunal Supremo respecto a la automaticidad en la concesión de las indemnizaciones en los casos de lesión de derechos fundamentales y libertades públicas. Sin embargo, aunque tilda de "irreprochable" esa nueva doctrina, también subraya que, en su sentencia de 28 de febrero de 2000, el Tribunal Supremo había argumentado "exclusivamente" sobre la falta de vigencia de la doctrina jurisprudencial representada por la STS de 9 de junio de 1993 y sobre la necesidad de aportar al proceso las pautas que permitan cuantificar el importe del daño a reparar.

Según el Tribunal Constitucional, la exposición detallada de la conducta causante de la vulneración del derecho fundamental de la que venía siendo víctima de manera prolongada en el tiempo permitía entender cumplida la exigencia jurisprudencial de alegación adecuada de "las bases y elementos clave" de la indemnización reclamada, y de acreditación en el proceso, cuando menos, de "indicios o puntos de apoyo suficientes" en los que se pueda asentar la condena indemnizatoria. Ello era así porque dicha conducta ocasionaba, además de los perjuicios económicos perfectamente cuantificables (reducción de jornada laboral con la consiguiente reducción salarial), daños morales “de más difícil cuantificación pero cuya realidad no puede negarse". La descripción de las circunstancias que rodeaban la vulneración del derecho (que ponían de manifiesto un trato discriminatorio derivado del ejercicio de funciones sindicales "de la intensidad y duración en el tiempo" acreditada en el relato de hechos probados) se considera, pues, suficiente para poner de manifiesto la existencia del daño moral y, por tanto, para que prosperase la reclamación, pues este tipo de daño "se da en todo caso, sin que sea factible a veces 
aportar prueba concreta del perjuicio sufrido y de su cuantificación monetaria, dada su índole".

Añade el Tribunal, por último, que el demandante tomando como referencia la LISOS, cuantificó la indemnización reclamada: "En tal sentido debe tenerse en cuenta que una conducta empresarial que pudiera estimarse constitutiva de discriminación antisindical constituye una infracción muy grave, de conformidad con el art. 8.12 del citado texto refundido, sancionable con multa que, en su grado máximo, puede rebasar con creces la cuantía reclamada por el demandante (art. 40.1 del texto refundido)".

\subsection{La deriva hacia el carácter automático de la indemnización}

Inicialmente, el pronunciamiento del Tribunal Constitucional mantuvo intacta la doctrina jurisprudencial anterior, ya que el Tribunal Supremo interpretó que la STC 247/2006, de 24 de julio, no había puesto en cuestión "la doctrina de esta Sala sobre el carácter no automático de la indemnización, sino su aplicación en un caso concreto" (STS de 12 de diciembre de 2007, Rec. 25/2007).

Sin embargo, la entrada en vigor de la LO 3/2007, de Igualdad Efectiva entre Mujeres y Hombres, permitía auspiciar una vuelta al carácter automático de las indemnizaciones por lesión de derechos fundamentales ${ }^{11}$. Así parecía deducirse, más concretamente, de la nueva redacción que la LO de Igualdad daba al artículo 181 de la LPL ("el Juez deberá pronunciarse sobre la cuantía de la indemnización"), y del uso del futuro imperativo en el artículo 10 de la Ley, que trataba, siguiendo la estela de las Directivas en materia de igualdad de sexos, las consecuencias jurídicas de las conductas discriminatorias ("darán lugar a responsabilidad a través de un sistema de reparaciones o indemnizaciones que sean reales, efectivas y proporcionadas al perjuicio sufrido, así como, en su caso, a través de un sistema eficaz y disuasorio de sanciones que prevenga la realización de conductas discriminatorias").

En realidad, como recalca la doctrina científica ${ }^{12}$, el análisis de la regulación de la ley procesal laboral en materia de indemnización por vulneración de derechos fundamentales es imposible de desgajar de las normas comunitarias sobre tutela antidiscriminatoria y, lógicamente, de la jurisprudencia del Tribunal de Justicia de la Unión europea que está en su origen. Cabe recordar a este respecto, por un lado, que, si bien el Tribunal de Justicia admitía que el Derecho comunitario (y, en concreto, la Directiva 76/207/CEE, del Consejo, de 9 de febrero de 1976) no imponía a los Estados miembros una medida determinada en caso de incumplimiento de la prohibición de discriminación, sí entendía que exigía medidas apropiadas para restablecer la igualdad efectiva de oportunidades

\footnotetext{
${ }^{11}$ GOERLICH PESET, José María, "La reparación de los daños morales derivados de lesión de un derecho fundamental por los tribunales del orden social: algunos pronunciamientos recientes del Tribunal Supremo", 2009, p. 3. Recuperado de http://online.elderecho.com.

12 Por todos, LOUSADA AROCHENA, José Fernando, La tutela de los derechos fundamentales y de las libertades públicas en la Ley Reguladora de la Jurisdicción Social, Albacete, Bomarzo, 2012, pp. 79-80.
} 
cuando no hubiese sido respetada que debían garantizar una tutela judicial efectiva y eficaz y surtir un efecto disuasorio real frente al empresario (STJCE de 10 de abril de 1984, asunto Von Colson y Kamann, C-14/83; STJCE de 2 de agosto de 1993, asunto Marshall, C-271/91). De ahí que, cuando la reparación pecuniaria fuese la medida adoptada, se exigiese que fuera adecuada en el sentido de que debía permitir compensar íntegramente los perjuicios efectivamente sufridos a causa de la discriminación, según las normas nacionales aplicables (STJCE de 2 de agosto de 1993, asunto Marshall, C271/91). Por otro lado, no cabe olvidar que el Tribunal había dispuesto la disconformidad con el derecho comunitario de las disposiciones legales nacionales que estableciesen $a$ priori un límite máximo a la indemnización de daños y perjuicios que puede obtenerse en caso de discriminación por razón de sexo con motivo de una contratación, salvo que el empresario pudiese probar que no se habría obtenido la plaza vacante aunque la selección se hubiera efectuado sin discriminaciones, debido a la superior cualificación del candidato contratado (STJCE de 22 de abril de 1997, asunto Draehmpaehl, C-180/95,).

Todo ello explica la literalidad del artículo 18 de la Directiva 2006/54/CE del Parlamento Europeo y del Consejo, de 5 de julio de 2006, relativa a la aplicación del principio de igualdad de oportunidades e igualdad de trato entre hombres y mujeres en asuntos de empleo y ocupación, que refunde en un solo texto las Directivas 76/207/CEE, del Consejo, de 9 de febrero de 1976 y 86/378/CEE, del Consejo, de 24 de julio de 1986, incorporando las novedades que derivaban de la jurisprudencia del Tribunal de Justicia. Según este precepto -similar al artículo 15 de la Directiva 2000/43/CE del Consejo, de 29 de junio de 2000, relativa a la aplicación del principio de igualdad de trato de las personas independientemente de su origen racial o étnico, y al artículo 17 de la Directiva Directiva 2000/78/CE del Consejo, de 27 de noviembre de 2000, relativa al establecimiento de un marco general para la igualdad de trato en el empleo y la ocupaciónlos Estados miembros introducirán en sus ordenamientos jurídicos nacionales "las medidas necesarias para garantizar la indemnización o la reparación, según determinen los Estados miembros, real y efectiva del perjuicio sufrido por una persona a causa de una discriminación por razón de su sexo, de manera disuasoria y proporcional al perjuicio sufrido. Dicha indemnización o reparación no podrá estar limitada por un tope máximo fijado a priori, excepto en aquellos casos en que el empresario pueda probar que el único perjuicio sufrido por el demandante como resultado de la discriminación en el sentido de la presente Directiva sea la negativa a tomar en consideración su solicitud de trabajo".

\subsection{La automaticidad de la indemnización tras la LRJS}

Con el tiempo, la doctrina del Tribunal Supremo evolucionó, llegándose a reconocer en alguna ocasión, incluso, que "dada la índole del daño moral, existen algunos daños de este carácter cuya existencia se pone de manifiesto a través de la mera acreditación de la lesión. Esto es lo que suele suceder, por ejemplo, con las lesiones del derecho al honor o con determinadas conductas antisindicales" (STS de 18 de julio de 2012, Rec. 126/2012). $\mathrm{Y}$, tras la entrada de vigor de la vigente regulación, la tesis de la automaticidad es la 
postura interpretativa que ha prevalecido finalmente, pues las precisiones efectuadas por el Tribunal Constitucional quedaron incorporadas a la literalidad de los artículos 179.3 y 183 de la LRJS, de manera que, si bien es exigible la identificación de las "circunstancias relevantes para la determinación de la indemnización solicitada", se contempla la excepción en el caso de los daños morales unidos a la vulneración del derecho fundamental cuando resulte difícil su estimación detallada (por todas, SSTS de 13 de diciembre de 2018, Rec. 3/2018 y de 24 de octubre de 2019, Rec. 12/2019).

Como se ha señalado desde la doctrina ${ }^{13}$, la incorporación de las apreciaciones del Tribunal Constitucional no tenía por qué haber implicado necesariamente una vuelta a la tesis del carácter automático del daño moral sino, más bien, el descarte, en aras de la protección del derecho a la tutela judicial efectiva, de pruebas diabólicas y de cuantificación compleja en la acreditación de los daños morales. Algún pronunciamiento del Tribunal Supremo (vid. STS de 5 de febrero de 2013, Rec. 89/2012) parecía apuntar, incluso, a que la entrada en vigor de la LRJS no iba a significar la automaticidad de la indemnización por daños morales, en la medida en que el reconocimiento del daño moral requiere tener en cuenta los factores concurrentes (gravedad de la conducta y sus efectos en la víctima) ${ }^{14}$.

No obstante, en la modificación de la doctrina de la Sala de lo Social había influido, además de los cambios legislativos, el criterio "aperturista" que actualmente informa el resarcimiento del daño moral, cuya aplicación, según señalaba el propio Tribunal, incluso se recomienda en el ámbito de los incumplimientos contractuales por los PETL "Principles of European Tort Law" o principios de derecho europeo de responsabilidad civil- y por UNIDROIT -Instituto Internacional para la Unificación del Derecho Privado(STS de 19 de diciembre de 2017, Rec. 624/2016). La jurisprudencia de la Sala primera del Tribunal recordaba, en este sentido, refiriéndose a la conexión objetiva del daño moral con el incumplimiento, que "a este principio responde el criterio que para la indemnización del daño moral se recomienda en los artículos 9:501 y 9:503 de los PETL, según los cuales, si no existe una cláusula penal que determine otra cosa, el resarcimiento incluye el daño moral, cuya extensión se limita a los daños que fueran previsibles al tiempo de la perfección del contrato y sean resultado del incumplimiento, salvo el caso de que éste sea doloso o debido a culpa grave, en que deberán indemnizarse todos los daños morales. La inclusión del daño moral en el deber de resarcimiento se prevé también

\footnotetext{
${ }^{13}$ LAHERA FORTEZA, Jesús, "Las acciones de indemnización de daños por vulneración de la libertad sindical tras la Ley 36/2011 de Jurisdicción Social", Relaciones Laborales, 8, 2012, p. 33; MANEIRO VÁZQUEZ, Yolanda, "El derecho a la indemnización por daños morales como consecuencia de la lesión de la libertad sindical a la luz de la sentencia TC 247/2006, de 24 de julio", Dereito: revista xurídica da Universidade de Santiago de Compostela, Vol.22, $\mathrm{n}^{\circ}$ ext.:245-263, 2013, pp. p. 258; BALLESTER PASTOR, María Amparo, "El proceloso camino hacia la efectividad y adecuación de las indemnizaciones por vulneración de derechos fundamentales", Revista de Derecho Social, 69, 2015, p. 46.

${ }^{14}$ BALLESTER PASTOR, María Amparo, "El proceloso camino hacia la efectividad y adecuación de las indemnizaciones por vulneración de derechos fundamentales", Revista de Derecho Social, 69, 2015, p. 46.
} 
en los Principios sobre contratos comerciales internacionales elaborados por UNIDROIT" (STS, Sala 1 ${ }^{\text {a }}$, de 15 de junio de 2010, Rec. 804/2006).

Igualmente, en la modificación del criterio jurisprudencial había influido la doctrina de la Sala de lo Civil del Tribunal acerca de la inexistencia de parámetros que permitan con precisión traducir en términos económicos "el sufrimiento en que el daño moral esencialmente consiste", lo que lleva, por una parte, a un mayor margen de discrecionalidad en la valoración y, por otra parte, "diluye en cierta medida la relevancia para el cálculo del quantum indemnizatorio" de la aplicación de parámetros objetivos, pues "los sufrimientos, padecimientos o menoscabos experimentados "no tienen directa o secuencialmente una traducción económica" (por todas, STS, Sala $1^{\mathrm{a}}$, de 28 de febrero de 2008, Rec. 110/2001).

Quizá por ello, una lectura atenta de la jurisprudencia más reciente hace difícil negar la existencia de una vuelta a la tesis de la automaticidad ${ }^{15}$ ajustada ahora, como no podía ser de otra forma, a los términos de la LRJS.

Efectivamente, según indica el propio Tribunal Supremo, en la actualidad debe considerarse, por un lado, que los daños morales resultan "indisolublemente unidos" a la vulneración del derecho fundamental y "cuando resulte difícil su estimación detallada" (lo que, no hay que olvidar, ocurrirá casi siempre ${ }^{16}$ ) deberán flexibilizarse, en lo necesario, las exigencias normales para la determinación de la indemnización.

Por otro lado, a juicio del Tribunal, como establece el artículo 15 LOLS, y conforme a los artículos 182 y 183 de LRJS, la sentencia estimatoria de la demanda de tutela de derechos fundamentales debe disponer, entre otros extremos, la reparación de las consecuencias de la infracción del derecho o libertad fundamental incluyendo expresamente la indemnización, toda vez que la indemnización forma parte integrante de la obligación de restablecimiento en la "integridad" del derecho o libertad vulnerados (SSTS de 17 de diciembre de 2013, Rec. 109/2012; 8 de julio de 2014, Rec. 282/2013; 2 de febrero de 2015, Rec. 279/2013; 26 de abril de 2016, Rec. 113/2015; 12 de julio de 2016, Rec. 361/2014; 8 de febrero de 2018, Rec. 274/2016; 6 de junio de 2018, Rec. 149/2017; o 21 de febrero de 2019, Rec. 214/2017).

\footnotetext{
${ }^{15}$ MOLINA NAVARRETE, Cristóbal, "El "plus de riesgo de despido" de las mujeres embarazadas: ¿"indemnización disuasoria" también para la nulidad objetiva? Comentario a la Sentencia del Tribunal Supremo 942/2017, de 28 de noviembre, Revista de Trabajo y Seguridad Social. CEF, 421, 2018, p. 136; SÁNCHEZ PÉREZ, José, "La reparación del daño en la jurisdicción laboral", Revista Española de Derecho del Trabajo, 216, 2019, pp. 22-23.

16 Por todos, BALLESTER PASTOR, María Amparo, "El proceloso camino hacia la efectividad y adecuación de las indemnizaciones por vulneración de derechos fundamentales", Revista de Derecho Social, 69, 2015, p. 45.
} 


\section{La cuantificación y fiscalización del importe indemnizatorio}

\subsection{La consideración de los factores concurrentes en la determinación de la indemnización}

No cabe confundir, con todo, el reconocimiento de la vulneración del derecho fundamental $-\mathrm{y}$ de los daños morales "indisolublemente unidos" a ella- con la determinación de la cuantía de la indemnización integrante de la reparación de dicho derecho ${ }^{17}$.

En este terreno, el Tribunal Supremo ha dispuesto que la cuantificación de los daños corresponde al juez de instancia, siendo solo revisable en los casos en que resulte "manifiestamente arbitraria, irrazonable o desproporcionada" (SSTS de 5 de febrero de 2013, Rec. 89/2012; o 17 de junio de 2014, Rec. 157/13), y ha considerado idónea la utilización del criterio orientador de las sanciones pecuniarias previstas por la LISOS, criterio expresamente admitido, a su vez, por la jurisprudencia constitucional en la sentencia 247/2006, de 24 de julio (SSTS de 15 de febrero de 2012, Rec. 67/2011; 8 de julio de 2014, Rec. 282/13; 29 de noviembre de 2017, Rec. 7/17; o 13 de diciembre de 2018, Rec. 3/2018).

Es importante, por ello, tener presente que, aunque, finalmente, el Tribunal Supremo no ha rechazado la automaticidad de la indemnización por daños morales por requerir el reconocimiento del daño moral la consideración de los factores concurrentes ${ }^{18}$, eso no significa que dichos factores (gravedad de la conducta, duración, consecuencias del daño) no jueguen un papel trascedente en la determinación de la indemnización: contrariamente, como demuestran sentencias recientes del propio Tribunal Supremo y los últimos pronunciamientos de los tribunales inferiores que acogen expresamente la última interpretación jurisprudencial en la materia, la consideración de los factores concurrentes puede ser decisiva en la cuantificación de la indemnización. Y es que, puesto que no existen normas para calcular la reparación correspondiente al daño moral, estos factores desarrollan una labor de condicionamiento objetivo de la tarea del juzgador que resulta, obviamente, necesaria, pues su valoración prudente y discrecional, si bien puede ocasionar indemnizaciones dispares, no puede confundirse, en ningún caso, con $\operatorname{arbitrariedad}^{19}$.

\footnotetext{
${ }^{17}$ MANEIRO VÁZQUEZ, Yolanda, "El derecho a la indemnización por daños morales como consecuencia de la lesión de la libertad sindical a la luz de la sentencia TC 247/2006, de 24 de julio", Dereito: revista xurídica da Universidade de Santiago de Compostela, Vol.22, nº ext.:245-263, 2013, p. 254.

${ }^{18}$ Opción que, según se ha indicado, pareció haberse tomado en un primer momento a la vista de la decisión adoptada en la STS de 5 de febrero de 2013 (Rec. 89/2012).

${ }^{19}$ MANEIRO VÁZQUEZ, Yolanda, "El derecho a la indemnización por daños morales como consecuencia de la lesión de la libertad sindical a la luz de la sentencia TC 247/2006, de 24 de julio", Dereito: revista xurídica da Universidade de Santiago de Compostela, Vol.22, no ext.:245-263, 2013, p. 254; SÁNCHEZ PÉREZ, J., "El proceso especial de tutela de los derechos fundamentales en la jurisdicción social y su vertiente reparadora", Derecho de las relaciones laborales, 9, 2016, p. 882.
} 
Como muestra de lo dicho puede servir de ejemplo la STS de 21 de febrero de 2019 (Rec. 214/2917), relativa a un supuesto de vulneración del derecho de libertad sindical por parte de una empresa que no permite al sindicato demandante la utilización del sistema de correo electrónico, en los mismos términos que admite por el contrario en favor de los demás sindicatos que actúan en la empresa. El Tribunal Supremo, además de aplicar la doctrina constitucional en la materia para considerar vulnerado el derecho fundamental en cuestión (por negarse injustificadamente la empresa a permitir la utilización del correo electrónico que ha facilitado a otras organizaciones sindicales, sin concurrir causas que pudiere hacer valer para oponerse a ello en razón de la posible afectación al normal desarrollo del proceso productivo, y estando acreditado que el sindicato en cuestión dispone de un cierto nivel de implantación en la empresa), confirma la indemnización por daños morales de 6.000 euros, frente a los 30.000 solicitados por el sindicato sin concretar los daños sufridos ni distinguir daños materiales y morales. Para ello, recuerda el Tribunal los parámetros que han llevado a la sentencia de instancia a fijar la indemnización por daños morales en la suma de 6.000 euros: "El primero, que la empresa no ha hecho manifestación alguna para oponerse a la cuantía reclamada en tal concepto por el demandante, a lo que añade que la vulneración se produce poco antes del inicio del litigio, que no ha quedado probado cuales hayan podido ser las concretas y específicas comunicaciones del sindicato que no han podido cursarse por el correo electrónico, que el sindicato las ha publicado sin embargo en el tablón de anuncios (...)Finalmente, que la empresa no ha aportado la más mínima justificación de su actuación y que debe atender también la finalidad disuasoria de la indemnización". Del mismo modo, recuerda el Tribunal Supremo, con cita de la sentencia de 6 de junio de 2018 (Rec. 149/2017), que la jurisprudencia de la Sala viene entendiendo que la cuantía que haya fijado prudencialmente el órgano judicial de instancia únicamente debe ser corregida o suprimida cuando se presente desorbitada, injusta, manifiestamente desproporcionada o claramente irrazonable. A partir de ahí, concluye que la indemnización resulta proporcionada atendiendo al gran volumen de trabajadores que emplea la recurrente (en cifra superior a 8.000 personas) y su consiguiente capacidad económica, la gravedad de la vulneración del derecho a la libertad sindical y la razonable cuantía que finalmente se ha fijado "y que respeta escrupulosamente lo dispuesto en el art. 183.2 LRJS, que atribuye al órgano judicial la facultad de fijarla prudencialmente cuando la prueba de su importe exacto resulta demasiado difícil o costosa".

Tratándose de tribunales inferiores, cabría mencionar el supuesto enjuiciado en la sentencia de la Audiencia Nacional de 7 de febrero de 2020 (sentencia núm. 12/2020), que resolvió la solicitud formulada por un delegado sindical sobre existencia de vulneración del derecho a la libertad sindical en su vertiente a la actividad sindical y acción sindical a través del derecho de información. El demandante solicitaba la declaración de la nulidad radical de la conducta de la demandada -consistente en el incumplimiento de la obligación legal de acceso a la misma información y documentación que la empresa pone a disposición del Comité de Empresa, y en concreto por vulneración 
del derecho a ser informado en todo lo relativo a protección marítima-, la condena a la demandada al cese de sus actuaciones vulneradoras de tal derecho y, por ende, a cumplir con lo dispuesto en la legislación y demás normativa vigente al efecto, así como al abono, con carácter adicional, de la indemnización de 6.250 euros por daños morales o a la cantidad que se considerase oportuna. Aunque la Audiencia Nacional declara la existencia de la vulneración del derecho a la libertad sindical, entiende que las particularidades del caso hacen desproporcionada la indemnización que se pide. Como punto de partida admite, siguiendo el criterio jurisprudencial, que para la cuantificación de la indemnización suelen tomarse como referencia las sanciones previstas para las conductas en la LISOS. En el caso enjuiciado, ello otorgaría, efectivamente, un margen para la fijación de la indemnización entre 626 y 6.250 euros, ya que el artículo 7.7 LISOS tipifica como falta grave "la transgresión de los derechos de información, audiencia y consulta de los representantes de los trabajadores y de los delegados sindicales" y, por su parte, el artículo 40.1.b) contempla como sanción una multa en su grado mínimo, de 626 a 1.250 euros, en su grado medio de 1.251 a 3.125 euros y en su grado máximo de 3.126 a 6.250 euros. Sin embargo, la Audiencia considera que, incluso en el caso de optarse por la cuantía mínima de la sanción, tal indemnización resultaría "desproporcionada a las circunstancias del caso", por lo que la cantidad de 25 euros se estima suficiente tanto para atender la finalidad resarcitoria como preventiva de la indemnización. Entre las circunstancias mencionadas destaca la Sala el mínimo quebranto producido al derecho de acción sindical -ya que la vulneración del derecho a la información se circunscribía a una información concreta y determinada que ya se encontraba en poder del sindicato- y la falta de evidencia de la buena fe del sindicato en aclarar su régimen organizativo -que derivaba de la existencia de contradicción entre la voluntad manifestada de establecer una única sección sindical de ámbito empresarial dejando sin efecto los nombramientos de las secciones sindicales de centro o provincia, y las pretensiones de las secciones sindicales de dicho ámbito de seguir operando de forma autónoma, con exigencia de garantías y derechos para sus delegados-.

La propia Audiencia Nacional modera también la cuantía de la indemnización reclamada en su sentencia de 14 de mayo de 2019 (núm. 65/2019), en la que se solicitaba que se declarase que la actuación de la empresa "retrasando, bloqueando, censurando y negándose a publicar" los comunicados de CCOO, suponía una vulneración del derecho de libertad sindical, y se pedía, en consecuencia, la condena al cese inmediato en ese comportamiento y a indemnizar con la cantidad de 60.000 euros. La sentencia, si bien reconoce que las conductas empresariales constituyen una violación frontal del derecho a la libertad sindical del sindicato CCOO en su manifestación de derecho de información y condena a la empresa a cesar de forma inmediata en su comportamiento, fija una indemnización de 15.000 euros. Para ello subraya, precisamente, que la fijación del importe de la indemnización por daños morales ha de ajustarse "a parámetros de razonabilidad que no resulten excesivos y desorbitados en función de las circunstancias del caso" (STS de 13 de julio de 2015, Rec. 221/2014). Al aplicar estos criterios al 
supuesto enjuiciado, la Sala considera necesario moderar "por considerar excesiva" la cuantía de la indemnización reclamada -de 60.000 a 15.000 euros que sí se reconocen, no obstante, "en aras a evitar la reiteración de la conducta antisindical de la empresa"- al tener en cuenta "la realidad de lo acaecido y a falta de elementos objetivos en la demanda para basar el cálculo de la indemnización".

En la misma línea, la STSJ de Castilla-La Mancha de 14 de enero de 2019 (Rec. 1822/2018) ratifica la sentencia de instancia tanto por lo que se refiere a la falta de justificación de la decisión adoptada por la empresa sobre modificación sustancial de condiciones de trabajo impuesta al actor, con vulneración del derecho fundamental a no ser discriminado por razones de carácter familiar, como por lo que respecta a la cuantía indemnizatoria. En relación con esta, el Tribunal de suplicación, partiendo de la efectiva dificultad que supone la determinación de la indemnización, entiende que la cantidad solicitada de 50.000 euros resulta claramente excesiva, no estando además acompañada de concreción o especificación alguna, siendo más realista "y ajustada a las circunstancias" la de la jueza "a quo" de 4.000 euros "lo que impone su mantenimiento, no existiendo razón específica que ponga de manifiesto la concurrencia de circunstancias especiales que justifiquen su alteración".

Por su parte, la del TSJ de Galicia de 29 de noviembre de 2018 (Rec. 2283/2018), estima solo en parte el recurso de suplicación planteado por el trabajador en un caso de despido nulo por vulneración del derecho de libertad sindical por concurrencia de indicios de represalia empresarial frente a la actividad reivindicativa laboral del trabajador. La sentencia de instancia, posteriormente complementada por auto, había desestimado la petición indemnizatoria ante la falta de acreditación por el actor del perjuicio causado, interpretando que no era procedente la concesión automática de la indemnización. En consecuencia, en suplicación se solicitaba el mantenimiento de la declaración de nulidad del despido y la condena a la empresa al pago de una indemnización por daños de 8.000 euros. En su sentencia, el Tribunal Superior de Justicia de Galicia recuerda que, tras el cambio jurisprudencial acaecido con la entrada en vigor de la LRJS, ya no es necesaria la acreditación concreta del daño moral y se admite como pauta válida el criterio orientador de la LISOS. Ello le lleva a conceder la indemnización, pero no en la cuantía propuesta en el recurso, sino en la inferior fijada en la LISOS. Así, a juicio del Tribunal, la aplicación de los parámetros jurisprudenciales debe conducir, atendiendo a las cuantías sancionatorias previstas en el artículo 40 de la LISOS para las infracciones muy graves del artículo 8 de la misma norma, al establecimiento de la cuantía indemnizatoria en la cantidad de 6.251 euros, que es la mínima prevista por el legislador para este caso, "sin que existan datos" que sustenten la elevación a los 8.000 euros que se solicitaba.

\subsection{La justificación del concreto importe indemnizatorio fijado por analogía con la LISOS}

La consideración de la gravedad de la conducta, de su duración, y de las consecuencias del daño resulta determinante, además, en la justificación de la concreta cuantía de la 
indemnización elegida. Es verdad que, según se ha visto, como método de cuantificación es reiterada ya la jurisprudencia que acoge la utilización del criterio orientador de las sanciones pecuniarias previstas por la LISOS. La doctrina vaticinó el éxito de esta valoración de daños conforme a la LISOS, dada la sencillez y objetividad del método ${ }^{20}$, y el miedo al vacío que generaba en los aplicadores jurídicos, acostumbrados al carácter tasado de las indemnizaciones en el orden social, la incertidumbre en cuanto a la cuantía de la indemnización ${ }^{21}$. Sin embargo, también es cierto que, a juicio del Tribunal Supremo, con la utilización de los elementos que ofrece la cuantificación de las sanciones de la LISOS, no se está haciendo "una aplicación sistemática y directa de la misma", sino que se trata de ceñirse "a la razonabilidad que algunas de esas cifras ofrecen para la solución del caso, atendida a la gravedad de la vulneración del derecho fundamental" (entre otras, SSTS de 15 febrero 2012, Rec. 67/2011, de 8 julio 2014, Rec. 282/2013, y de 2 febrero 2015, Rec. 279/2013).

No extraña, pues, que sean los factores concurrentes los que permiten a los tribunales decantarse por una u otra calificación y grado de la infracción, a la hora de fijar la indemnización por daños morales por analogía con la posible multa que se impondría por una infracción de la LISOS.

Como ejemplo de ello es interesante destacar la fijación de una sanción de 6.000 euros correspondiente a la posible multa por infracción grave (artículo 7, apartados 7 y 8 LISOS) en su grado máximo (artículo 40.1 b) LISOS)- en la sentencia de la Audiencia Nacional de 14 de enero de 2020 (sentencia núm. 2/2020), por tomar en consideración la concreta conducta de la empresa al entorpecer la labor del sindicato USO, despojándole de los medios con que había contado los últimos años, sin justificación alguna y precisamente en el momento previo a la celebración de elecciones sindicales en importantes centros de trabajo.

Ya en suplicación cabría mencionar la sentencia del TSJ del País Vasco de 11 de diciembre de 2018 (Rec. 2204/2018), que eleva los daños morales de 40.000 a 50.000 euros, en un caso de una discriminación por razón de género (en la promoción profesional), al admitir en parte la revisión fáctica propuesta y tener en cuenta otras circunstancias que modulan las ya fijadas por la instancia. Cabe también hacer referencia a la imposición en la STSJ del País Vasco de 15 de noviembre de 2019 (Rec. 1862/2019), en un caso de esquirolaje tecnológico, de una multa de 3.125 euros para cada trabajador y 3.125 para cada sindicato (correspondiente al tramo medio de las infracciones graves

\footnotetext{
${ }^{20}$ GOERLICH PESET, José María, "La reparación de los daños morales derivados de lesión de un derecho fundamental por los tribunales del orden social: algunos pronunciamientos recientes del Tribunal Supremo", p. 4. Recuperado de http://online.elderecho.com.

21 Entre otros, BALLESTER PASTOR, María Amparo, "El proceloso camino hacia la efectividad y adecuación de las indemnizaciones por vulneración de derechos fundamentales", Revista de Derecho Social, 69, 2015, p. 33; MOLINA NAVARRETE, Cristóbal, Indemnizaciones disuasorias, nueva garantía de efectividad de la tutela social: entre retórica judicial y prácticas innovadoras, Albacete, Bomarzo, 2019, pp. 11-12.
} 
según lo dispuesto en los artículos 7, apartado 8, y 40 LISOS) por atender el tribunal al número de trabajadores, a la falta de demostración del esquirolaje externo -únicamente se prueba el tecnológico-, y a la inexistencia de acreditación "de otras especiales circunstancias" que permitan reconocer una indemnización de mayor cuantía para valorar el daño causado. Igualmente, es significativa la elección del grado mínimo en otro pronunciamiento relativo a la vulneración del derecho de huelga para concretar la cuantía de la indemnización (6.251 euros, en aplicación de los artículos 8.10 y 40.1 c) LISOS) en la sentencia del mismo tribunal de 5 de noviembre de 2019 (Rec. 1814/2019), en la que se afirma que la inexistencia de móvil atentatorio del derecho fundamental (la empresa amplía los servicios mínimos acordados por el Gobierno Vasco al acomodar su actuación a modos de obrar en anteriores huelgas) no obsta al comportamiento lesivo, pero sí modula la indemnización.

Es posible destacar, asimismo, la consideración expresa en la STSJ de Andalucía de 30 de octubre de 2019 (Rec. 2253/2019), sobre vulneración de la libertad sindical, de la reincidencia como el factor que justifica la elección de la concreta cuantía indemnizatoria. La sentencia considera, en efecto, que procede fijar la indemnización por daños morales en 6.250 euros teniendo en cuenta que, primero, el comportamiento de la empresa encuentra acomodo en la infracción tipificada como grave en el artículo 7.8 LISOS; y que, segundo, la reincidencia en la conducta justifica "su incardinación en el grado máximo y la aplicación de la cantidad superior de la horquilla correspondiente”.

O, en fin, podría señalarse que la confirmación en la STSJ de Canarias (Santa Cruz de Tenerife) de 24 de septiembre de 2019 (Rec. 1103/2019), sobre vulneración del derecho a la ejecución efectiva de las resoluciones judiciales, de una indemnización por daños morales de 10.000 euros (correspondientes a una falta muy grave, aunque dentro del grado mínimo), frente a los 25.000 solicitados sin ningún criterio de cuantificación, queda justificada porque atiende a la gravedad de la actuación empresarial y al mantenimiento en el tiempo de la misma.

\section{La finalidad preventiva de la indemnización por vulneración de derechos fundamentales}

El retorno jurisprudencial a la tesis del carácter automático del daño moral -ajustada ahora, según se ha indicado, a los términos de la LRJS- no ha zanjado, ni mucho menos, el debate en torno a la determinación de la indemnización en caso de vulneración de derechos fundamentales. Al margen de las dificultades que, según se ha visto, puede plantear la cuantificación del daño moral, hay que tener presente que tras la entrada en vigor de la LRJS la indemnización debe cumplir no solo una finalidad resarcitoria de los daños materiales y morales, sino, también, a decir de su artículo 183, una finalidad preventiva. Pues bien, tal indicación resulta especialmente problemática debido a la posible conexión existente entre esa finalidad preventiva a la que, según la ley procesal, 
debe contribuir la indemnización y la incorporación de los (mal) llamados daños punitivos ("punitive damages") a nuestro ordenamiento 22 .

\section{El debate sobre la equivalencia entre la función preventiva y el carácter punitivo de la indemnización}

\subsection{La discutida figura de los daños punitivos}

Los daños punitivos, de origen británico y generalizados con posterioridad en el sistema norteamericano -si bien es cierto que en casos de extraordinaria gravedad y de conducta especialmente dolosa y antisocial del infractor- no cuentan, como es sabido, con una aceptación general en el derecho continental, por mucho que, en los últimos años, se hayan detectado ciertos cambios y sea posible mencionar ejemplos de incorporaciones concretas en países de tradición no anglosajona. En efecto, mientras en los países del common law el sistema de responsabilidad civil se ha visto enriquecido con una función "moralizante", pues se permite al tribunal civil condenar al pago de una cantidad en concepto de daños punitivos como castigo y como medida de prevención, en derecho continental la responsabilidad civil privada y la responsabilidad penal o administrativa han contado tradicionalmente con una separación estricta: la responsabilidad civil desarrolla, esencialmente, una función reparadora del perjuicio causado, y las normas del Derecho penal y administrativo se encargan de las funciones propias de la "política social", es decir, de la prevención de los daños y del castigo de los comportamientos socialmente intolerables ${ }^{23}$.

Como recordaba el Abogado General Paolo Mengozzi en sus conclusiones al asunto Arjona Camacho, C-407/2014, la figura de los daños punitivos puede considerarse una expresión de la teoría de la pena privada, pues no tratan sólo de reparar, sino también "de conceder, además de la reparación íntegra, una cantidad que se espera que, por su carácter sancionador, disuada no sólo al autor del perjuicio de repetir, en el caso en cuestión, su comportamiento (...) sino también al resto de actores de actuar de tal modo". En consecuencia, se considera, con carácter general, que la instauración de estos daños

\footnotetext{
${ }^{22}$ Como ha puesto de manifiesto la doctrina -CARRASCOSA GONZÁLEZ, Javier, "Daños punitivos. Aspectos de derecho internacional privado europeo y español", en: HERRADOR GUARDIA, Mariano José (dir.), Derecho de daños, 2013, p. 3. Recuperado de http://www.accursio.com/private/uploads/111_UMU__Punitive_Damages_by_J_Carrascosa.pdf; TEBALÁN PALACIOS, Herberth Isamar, "La reformulación de la indemnización por daños en el proceso especial de tutela de derechos fundamentales laborales", Trabajo y Derecho, 49, 2019, p. 3- en lengua inglesa, "damage", en singular, equivale a "daño", mientras que "damages" significa "indemnización”. En consecuencia, son las indemnizaciones, y no los daños, las que son "punitivas".

${ }^{23}$ Entre otros muchos, CARRASCOSA GONZÁLEZ, Javier, "Daños punitivos. Aspectos de derecho internacional privado europeo y español”, en: HERRADOR GUARDIA, Mariano José (dir.), Derecho de daños, 2013, pp. 4-8. Recuperado de http://www.accursio.com/private/uploads/111_UMU__Punitive_Damages_by_J_Carrascosa.pdf, pp. 4-8; REGLERO CAMPOS, Luis Fernando, “Conceptos generales y elementos de delimitación”. En: Nuevos clásicos. Tratado de Responsabilidad Civil, Aranzadi, 2014, pp. 25 y ss. de la versión electrónica; BALLESTER PASTOR, María Amparo, "El proceloso camino hacia la efectividad y adecuación de las indemnizaciones por vulneración de derechos fundamentales", Revista de Derecho Social, 69, 2015, pp. 35 y 37.
} 
punitivos resultaría especialmente problemática: por un lado, porque ello podría percibirse como la introducción de un instrumento jurídico cuasi penal en el ámbito de la responsabilidad civil; y, por otro lado, porque la instauración obligatoria de los daños punitivos podría menoscabar el principio de prohibición del enriquecimiento sin causa, que existe en la mayoría de los Estados.

Pese a ello, no cabe desconocer la existencia de voces proclives a la admisión, con las necesarias cautelas, de los "punitive damages". Desde este punto de vista se entiende, en apretada síntesis, que su introducción coadyuvaría a dotar a la responsabilidad civil de una función disuasoria más eficaz, lo cual sería totalmente deseable, pues el sistema de disuasión desplegado por los órdenes penal y administrativo no es siempre suficiente (así, por ejemplo, en muchos casos el responsable asume las consecuencias sancionatorias confiando en que su patrimonio permanecerá prácticamente intacto). La finalidad fundamental de los daños punitivos debería ser, por tanto, reforzar el papel preventivo de la responsabilidad civil, cumpliendo, según se adelantó, tanto una finalidad de prevención especial como de prevención general. Además, los partidarios de esta postura -aunque admiten que la posibilidad de que los daños punitivos originen un enriquecimiento injustificado de la víctima constituye el argumento de mayor enjundia en su contrarecuerdan que la indemnización punitiva únicamente se puede imponer en el caso de conductas particularmente intolerables, atendiendo a las circunstancias que concurran en el caso concreto, siendo esa exigencia de "intolerabilidad" presupuesto inexcusable de aplicación de los daños punitivos. Resultaría necesaria, en consecuencia, la tipificación legal de la conducta que puede acarrear la imposición de este tipo de indemnización ${ }^{24}$.

\subsection{La integración de los daños punitivos en la Ley Reguladora de la Jurisdicción social}

En nuestro país, aun reconociéndose la doble finalidad de la indemnización por vulneración de derechos fundamentales (reparadora, por un lado, y disuasoria-represiva, por otro), la concesión de una suma adicional en concepto de daños punitivos ha generado, con carácter general, por influencia de la concepción continental de la responsabilidad civil, rechazo, de manera que se ha entendido que la función disuasoria queda satisfecha por medio de la aplicación de sanciones administrativas ${ }^{25}$.

\footnotetext{
${ }^{24}$ Por todos, REGLERO CAMPOS, Luis Fernando, "Conceptos generales y elementos de delimitación". En: Nuevos clásicos. Tratado de Responsabilidad Civil, Aranzadi, 2014, pp. 23, 25, y 36-38 de la v.e. y la bibliografía que allí se cita.

25 Así lo subrayan, por ejemplo, TEBALÁN PALACIOS, Herberth Isamar, "La reformulación de la indemnización por daños en el proceso especial de tutela de derechos fundamentales laborales", Trabajo y Derecho, 49, 2019, pp. 5-6; CARRASCOSA GONZÁLEZ, Javier, "Daños punitivos. Aspectos de derecho internacional privado europeo y español”, en: HERRADOR GUARDIA, Mariano José (dir.), Derecho de daños, 2013, pp. 4-8. Recuperado de http://www.accursio.com/private/uploads/111_UMU__Punitive_Damages_by_J_Carrascosa.pdf, pp. 8-9; BALLESTER PASTOR, María Amparo, "El proceloso camino hacia la efectividad y adecuación de las indemnizaciones por vulneración de derechos fundamentales", Revista de Derecho Social, 69, 2015, pp. 35-37.
} 
De hecho, es posible hacer referencia a pronunciamientos judiciales -como la sentencia del Juzgado de lo Social $n^{\circ} 2$ de Guadalajara de 10 de octubre de 2011- que expresamente descartan la idea: "el daño debe ser reparado íntegramente, pero la reparación del daño solo puede alcanzar a los perjuicios sufridos, incluidos los daños morales, pero no puede incorporar cantidades con efectos disuasorios o ejemplificadores para conductas futuras o de cara a terceros". El propio Tribunal Supremo (STS de 18 de julio de 2012, Rec. 126/2011) negó, en algún caso, incluso, el carácter disuasorio de la indemnización: "la sentencia ha contado para el reconocimiento de la indemnización con los datos relativos al comportamiento empresarial que da lugar a la declaración de nulidad y la parte actora le ha formulado en el hecho décimo de la demanda las alegaciones sobre las consecuencias de la actitud vulneradora, que permiten afirmar la existencia de los parámetros necesarios para el cálculo, prescindiendo, desde luego, de toda consideración "disuasoria" por no constituir ni objetivo ni contenido de la extensión indemnizatoria".

En otras ocasiones, el reconocimiento de la finalidad disuasoria de la indemnización ha aparecido claramente referido a la reparación del daño moral: "si el órgano judicial entendiese probada la violación del derecho de libertad sindical, acordará entre otras medidas, mediante la indemnización que proceda (art. 179.1 LPL — hoy 183 LRJS —) la reparación de sus consecuencias ilícitas una de las cuales es el daño moral valorable según las circunstancias del caso y la gravedad de la lesión(...). La simple restitución del perjuicio económico estricta no compensa de la lesión del derecho, ni impide la reproducción de la actividad lesiva en el futuro. Así es como la indemnización ha de comprender, en supuestos de violación de un derecho fundamental, los perjuicios morales, presumiéndose la existencia del perjuicio, siempre que se acredita la intromisión ilegítima" (STSJ de Cataluña de 15 de marzo de 1993, sentencia núm. 1574/1993). Esta identificación, a la que no es ajena parte de la doctrina anglosajona, debe, sin embargo, desecharse pues, como se ha analizado supra, en los daños punitivos concurre una dimensión disuasoria "social" o una función de prevención general -consistente en prevenir, evitar y desincentivar que terceras personas cometan los actos ilegales de que se trate- que no está presente en los daños morales ${ }^{26}$.

Es verdad, por otra parte, que el TJUE, en la sentencia de 17 de diciembre de 2015, asunto C-407/2014, Arjona Camacho, entendió que, la Directiva 2006/54/CE, del Parlamento Europeo y del Consejo, de 5 de julio de 2006, relativa a la aplicación del principio de igualdad de oportunidades e igualdad de trato entre hombres y mujeres en asuntos de empleo y ocupación, a falta de disposición en el ordenamiento español que permita el abono de daños punitivos, no prevé que el juez nacional pueda condenar por sí mismo al

26 En este sentido, CARRASCOSA GONZÁLEZ, Javier, "Daños punitivos. Aspectos de derecho internacional privado europeo y español”, en: HERRADOR GUARDIA, Mariano José (dir.), Derecho de daños, 2013, p. 6 Recuperado de http://www.accursio.com/private/uploads/111_UMU__Punitive_Damages_by_J_Carrascosa.pdf, pp. 8-9; BALLESTER PASTOR, María Amparo, "El proceloso camino hacia la efectividad y adecuación de las indemnizaciones por vulneración de derechos fundamentales", Revista de Derecho Social, 69, 2015, p. 39. 
autor de una discriminación al abono de tales daños. No obstante, también es cierto, como la propia sentencia reconoce, olvidando hacer un análisis de lo que realmente establece el artículo 183.2 $\mathrm{LRJS}^{27}$, que fue el tribunal remitente quien señala que el concepto de daños punitivos no existe en derecho español.

En efecto, el Juzgado de lo Social n ${ }^{\circ} 1$ de Córdoba debía resolver una demanda interpuesta con el fin de lograr, por un lado, una declaración de la nulidad del despido de una trabajadora por constituir una discriminación por razón de sexo; y de obtener, por otro lado, una reparación, solicitando para ello la concesión de 6.000 euros de indemnización en concepto de daños morales. El juez declara la nulidad del despido, por considerar probado que constituye una discriminación por razón de sexo, e informa al Tribunal de Justicia de su intención de conceder a la demandante un importe de 3.000 euros en concepto de indemnización por daños y perjuicios, importe que, según él y en aplicación del Derecho nacional, resulta suficiente para la justa reparación del daño sufrido. Sin embargo, el juez alberga dudas en cuanto al carácter suficiente de esta compensación, puesto que considera que la indemnización por daños y perjuicios no persigue objetivos distintos del de reparación, mientras que la Directiva 2006/54, concretamente su artículo 18, parece exigir también a los Estados miembros medidas que tengan por objeto disuadir a los autores de la discriminación de adoptar de nuevo tal comportamiento. Entiende el juez que este objetivo de disuasión se alcanzaría si pudiera condenar al empresario al pago de 3.000 euros adicionales en concepto de lo que califica de "daños punitivos"; pero como este concepto es ajeno a la tradición jurídica española, el Derecho nacional no le faculta para dictar tal condena. De ahí la literalidad de la decisión prejudicial presentada por el Juzgado de lo Social número 1 de Córdoba el 27 de agosto de 2014, que no dejan lugar a dudas: "El artículo 18 de la Directiva 2006/54/CE, cuando predica el carácter disuasorio (además de real, efectivo y proporcional al perjuicio sufrido) de la indemnización de la víctima de una discriminación por razón de su sexo, ¿puede interpretarse en el sentido de que autoriza al juez nacional la condena verdaderamente adicional por daños punitivos razonables: esto es, por una suma adicional que, aun estando más allá de la reparación íntegra de los daños y perjuicios reales sufridos por la víctima, sirva como ejemplo para otros (además del propio autor del daño), pero siempre que dicha suma se mantenga dentro de los límites de lo que no es desproporcionado; $e$ inclusive cuando esta figura de los daños punitivos resulte ajena a la propia tradición jurídica del juez nacional?".

Este planteamiento -que en ningún momento menciona la finalidad preventiva que también debe cumplir la indemnización por prescripción legal- condiciona absolutamente, además de las conclusiones del Abogado General ${ }^{28}$, el sentido de la

\footnotetext{
${ }^{27}$ Por todos, TEBALÁN PALACIOS, Herberth Isamar, "La reformulación de la indemnización por daños en el proceso especial de tutela de derechos fundamentales laborales", Trabajo y Derecho, 49, 2019, p. 5.

28 En ellas se afirma que "Podría demostrarse verdaderamente problemático para algunos Estados miembros, comenzando por el Reino de España, instaurar estos daños punitivos".
} 
sentencia. La lectura detenida de la misma demuestra, ciertamente, que la práctica totalidad del razonamiento del Tribunal de Justicia se centra en dos objetivos: confirmar, en primer lugar, que el artículo 18 de la Directiva 2006/54 no prevé el abono de daños punitivos $^{29}$; y subrayar, en segundo lugar, que el artículo 25 de la Directiva citada permite a los Estados miembros adoptar medidas que establezcan el abono de daños punitivos a la víctima de una discriminación por razón de sexo "pero no lo impone". Tras sentar ambas premisas, es cuando el Tribunal afirma, sin más indagaciones, que "en el caso de autos, el tribunal remitente señala que el concepto de "daños punitivos" no existe en Derecho español"; para concluir declarando "en estas circunstancias, a falta de disposición del Derecho nacional que permita el abono de daños punitivos a la víctima de una discriminación por razón de sexo, el artículo 25 de la Directiva 2006/54 no prevé que el juez nacional pueda condenar por sí mismo al autor de esta discriminación al abono de tales daños".

El problema es que el planteamiento del juzgado, condicionante del fallo, resulta absolutamente limitado por varias razones. La más llamativa es que considera, según se ha adelantado, que la indemnización por daños y perjuicios no persigue objetivos distintos del de la reparación, haciendo caso omiso a un mandato legal que no deja resquicio de duda al referirse expresamente a la finalidad preventiva. Pero, además, obvia cualquier referencia relativa a la presencia de la figura de los daños punitivos en el ordenamiento español, pese a la existencia de instrumentos -como son los recargos de prestaciones de Seguridad Social (artículo 164 LGSS) o el auto de resolución del incidente de no readmisión, en el que se permite la fijación de una indemnización adicional (artículo 281 LRJS)- que suelen ponerse como ejemplo de la posible determinación de los mismos ${ }^{30}$.

Al partir de un planteamiento tan limitado y carecer de reflexión alguna en torno al alcance que debe tener la finalidad preventiva de la indemnización, el pronunciamiento del Tribunal de Justicia en el asunto Arjona Camacho se encuentra muy lejos de haber cerrado definitivamente la cuestión. No es imposible, en consecuencia, a la vista de la literalidad de la ley, admitir que, a través del componente preventivo de las indemnizaciones por vulneración de derechos fundamentales, se produce la integración

\footnotetext{
29 "Por consiguiente, debe declararse que, al igual que el artículo 6 de la Directiva 76/207 y para que el perjuicio sufrido debido a una discriminación por razón de sexo tenga una indemnización o reparación efectiva de forma disuasoria y proporcionada, el artículo 18 de la Directiva 2006/54 obliga a los Estados miembros que elijan la forma pecuniaria a introducir en su ordenamiento jurídico interno medidas que prevean el abono de una indemnización que cubra íntegramente el perjuicio sufrido, según los procedimientos que determinen, a la persona que ha sufrido un perjuicio, pero no prevé el abono de daños punitivos". La interpretación del mencionado artículo 18 por parte del TJUE se remite a lo dicho, supra, en el apartado III.1.3.

${ }^{30}$ Por todos, REGLERO CAMPOS, Luis Fernando, "Conceptos generales y elementos de delimitación". En: Nuevos clásicos. Tratado de Responsabilidad Civil, Aranzadi, 2014, pp. 34 y ss. de la versión electrónica; BALLESTER PASTOR, María Amparo, "El proceloso camino hacia la efectividad y adecuación de las indemnizaciones por vulneración de derechos fundamentales", Revista de Derecho Social, 69, 2015, p. 38.
} 
de los daños punitivos en este concreto aspecto de nuestro ordenamiento ${ }^{31}$. Ahora bien, de ser ello así, no cabe olvidar que el presupuesto para la imposición de indemnizaciones punitivas es la existencia de conductas tipificadas por la norma -en nuestro caso, lesiones de derechos fundamentales o libertades públicas- que resulten, atendiendo a las circunstancias que concurran en el caso concreto, excepcionalmente graves o intolerables.

\section{La recepción judicial de la nueva función de prevención general asignada a la indemnización}

En cualquier caso, la necesidad de tomar en consideración la finalidad preventiva de la indemnización es, a día de hoy, una cuestión sobre la que cabe poca discusión. La jurisprudencia más reciente (SSTS de 17 de diciembre de 2013, Rec. 109/2012; 8 de julio de 2014, Rec. 282/2013; 2 de febrero de 2015, Rec. 279/2013; 26 de abril de 2016, Rec. 113/2015; 12 de julio de 2016, Rec. 361/2014; 8 de febrero de 2018, Rec. 274/2016; 6 de junio de 2018, Rec. 149/2017; o 21 de febrero de 2019, Rec. 214/2017) es clara al respecto, al afirmar que, de lo dispuesto en los artículos 179.3 y 183.2 LRJS, se deduce que, la facultad atribuida al tribunal de determinar "prudencialmente" la cuantía del daño obliga a tener en cuenta que el importe indemnizatorio que se fije judicialmente debe ser suficiente no solo para la reparación íntegra, sino, además "para contribuir a la finalidad de prevenir el daño, es decir, fijando expresamente los principios de suficiencia y de prevención". Se admite, pues, ya sin vacilación alguna, que el art. 183.2 LRJS viene a asignar a la indemnización no sólo una función resarcitoria (la utópica restitutio in integrum), sino también la de prevención general (STS de 5 febrero y 13 julio 2015, Rec. 77/2014 y 221/2014; 18 mayo y 2 noviembre 2016, Rec. 37/2015 y 262/2015; 24 enero y 19 diciembre 2017, Rec. 1902/2015 y 624/2016; o de 13 de diciembre de 2018, Rec. 3/2018).

Otro tema es que sean poco frecuentes todavía, como ha puesto de relieve la doctrina ${ }^{32}$, los pronunciamientos que conceden una partida indemnizatoria diferenciada destinada a "prevenir el daño". Existen, con todo, excepciones que merecen ser destacadas. Así, la necesidad de que la indemnización contribuya a la finalidad de prevenir el daño condujo a la STSJ del País Vasco de 17 de julio de 2018 (Rec. 128/2018) a incrementar la indemnización concedida (de 20.000 euros) en 12.000 euros, por considerar que la reiteración de la conducta del Servicio Vasco de Salud (condenado por hechos similares

\footnotetext{
${ }^{31}$ En este sentido, BALLESTER PASTOR, María Amparo, "El proceloso camino hacia la efectividad y adecuación de las indemnizaciones por vulneración de derechos fundamentales", Revista de Derecho Social, 69, 2015, pp. 34-43; o TEBALÁN PALACIOS, Herberth Isamar, "La reformulación de la indemnización por daños en el proceso especial de tutela de derechos fundamentales laborales", Trabajo y Derecho, 49, 2019, p. 17.

32 MOLINA NAVARRETE, Cristóbal, Indemnizaciones disuasorias, nueva garantía de efectividad de la tutela social: entre retórica judicial y prácticas innovadoras, Albacete, Bomarzo, 2019, pp. 11 y ss., muy crítico con la práctica forense; SÁNCHEZ PÉREZ, José, "La reparación del daño en la jurisdicción laboral”, Revista Española de Derecho del Trabajo, 216, 2019, p. 24.
} 
-riesgos psicosociales- por el propio Tribunal) es una circunstancia que no fue valorada en la instancia a efectos indemnizatorios.

No debe perderse de vista, de todas formas, a mi juicio, que el modo en que la finalidad preventiva quede reflejada a la hora de establecer la cuantía de la indemnización -que, cabe recordar, corresponde al juez de instancia, siendo solo revisable en los casos en que resulte "manifiestamente arbitraria, irrazonable o desproporcionada"- puede variar, ya que, como sucede con la cuantificación del daño moral, los factores concurrentes serán determinantes en esta tarea ${ }^{33}$. Ello resulta especialmente claro de admitirse que los daños punitivos han quedado incorporados en este concreto aspecto, pues, como se dijo, este tipo de daños aparecen necesariamente unidos a conductas especialmente dolosas y antisociales del infractor.

Es posible, por lo tanto, que, en muchas ocasiones, con una indemnización que resarza suficientemente a la víctima se haya cumplido ya la función preventiva en sus dimensiones individual y social, sin que sea precisa una partida indemnizatoria diferenciada destinada a este fin $^{34}$. Cabe imaginar, en definitiva, diferentes escenarios:

En casos como el enjuiciado en la mencionada STSJ del País Vasco de 17 de julio de 2018 (Rec. 128/2018), la falta de consideración de la finalidad preventiva deberá conducir, en efecto, máxime ante la reiteración de la conducta infractora, al reconocimiento de una partida diferenciada consagrada a este fin específico.

Incluso, habrá casos en que la finalidad preventiva será la única a tener en cuenta, al no existir daño material ni moral a resarcir, para fijar la indemnización. Así lo ha admitido ya expresamente, además, el propio Tribunal Supremo en la STS de 16 de febrero de 2017 (Rec. 90/2016) en un supuesto de vulneración reincidente del derecho de libertad sindical por parte de la Administración: "Son dos los aspectos a los que el artículo 183 de la LJS

\footnotetext{
${ }^{33}$ Resulta interesante destacar que un sector de la doctrina (BALLESTER PASTOR, María Amparo, "El proceloso camino hacia la efectividad y adecuación de las indemnizaciones por vulneración de derechos fundamentales", Revista de Derecho Social, 69, 2015, pp. 55-56) se ha mostrado contrario al uso de la capacidad económica de la empresa para ajustar a la baja el peso que debe tener la finalidad preventiva o disuasoria en el montante total de la indemnización, por entender que los daños patrimoniales no quedarían rebajados como consecuencia de la aplicación de tal criterio. Otro sector, en cambio, adopta una postura más matiza, aceptando que la finalidad preventiva tenga más peso cuanto mayor sea la capacidad económica de la empresa, pese a que ello pueda suponer una ventaja para los trabajadores de dichas empresas (MANEIRO VÁZQUEZ, Yolanda, "El derecho a la indemnización por daños morales como consecuencia de la lesión de la libertad sindical a la luz de la sentencia TC 247/2006, de 24 de julio", Dereito: revista xurídica da Universidade de Santiago de Compostela, Vol.22, no ext.:245-263, 2013, p. 262; SÁNCHEZ PÉREZ, José, "La reparación del daño en la jurisdicción laboral", Revista Española de Derecho del Trabajo, 216, 2019, p. 29.

${ }^{34}$ BALLESTER PASTOR, María Amparo, "El proceloso camino hacia la efectividad y adecuación de las indemnizaciones por vulneración de derechos fundamentales", Revista de Derecho Social, 69, 2015, pp. 34 y 39; TEBALÁN PALACIOS, Herberth Isamar, "La reformulación de la indemnización por daños en el proceso especial de tutela de derechos fundamentales laborales", Trabajo y Derecho, 49, 2019, p. 13. SÁNCHEZ PÉREZ, José, “La reparación del daño en la jurisdicción laboral”, Revista Española de Derecho del Trabajo, 216, 2019, p. 24, entiende, sin embargo, que los actores deberían desglosar las partidas que integran la indemnización con objeto de evitar que se unifiquen las finalidades legalmente previstas.
} 
dispensa protección, el daño unido a los perjuicios y la contribución a prevenir el daño. La sentencia recurrida niega la producción del daño ya que la finalidad de información ha sido satisfecha (...). No obstante resta la satisfacción del otro aspecto al que se refiere el artículo 183 de la LJS, contribuir a la prevención, que en este caso se acentúa por ser la segunda vez de la que se tiene noticia que los demandantes han acudido nuevamente y por la misma conducta aunque en diferente momento a recabar la declaración de que su derecho ha sido vulnerado. La reiteración en el comportamiento de la demandada hace evidente que una previa declaración de vulneración del derecho fundamental no ha contribuido a prevenir el ilícito. Esa razón y lo imperativo de la norma determinan que la pretensión indemnizatoria deba ser estimada en parte y cuantificada fundadamente en la cantidad de 6.000 euros...".

En otros casos, sin embargo, sin necesidad de reconocer una cuantía adicional específica con efectos disuasorios, será suficiente con valorar de forma conjunta el cumplimiento de las finalidades -resarcitoria y preventiva- que debe reunir la indemnización a la hora de concederla o a la hora de ponderar el montante de la indemnización concedido. A modo de ejemplo, cabría aludir a la adición de una indemnización de 6.000 euros en la STSJ de Madrid de 21 de noviembre de 2019 (Rec. 514/2019), en un supuesto de despido con vulneración de derechos fundamentales, por atender a la más reciente doctrina del Tribunal Supremo, alejada, según se indica de forma explícita al justificar la cantidad otorgada, del objetivo propiamente resarcitorio "para situarse en un plano que no descuida el aspecto preventivo que ha de corresponder a la indemnización en casos como el presente". Por su parte, la STSJ del País Vasco de 17 de diciembre de 2019 (Rec. 2113/2019), estima "como ponderada la indemnización de 6.251 euros solicitados (...) atendiendo a la finalidad resarcitoria y preventiva que se ha de buscar a la hora de fijar la indemnización". Idéntica consideración acerca de "la finalidad resarcitoria y preventiva que se ha de buscar a la hora de fijar la indemnización" lleva, en fin, a la sentencia del mismo Tribunal de 5 de noviembre de 2019 (Rec. 1802/2019) a declarar como ponderada la indemnización solicitada de 6.251 euros, frente a los 3.000 euros fijados en la sentencia.

\section{La indemnización por vulneración de derechos fundamentales en caso de nulidad "objetiva" del despido}

La concesión de la indemnización objeto de análisis plantea, finalmente, una cuestión que está dando lugar a interpretaciones encontradas y que, a diferencia de las anteriores, todavía no ha sido objeto de consideración -sin perjuicio de lo que después se dirá- por el Tribunal Supremo. Se trata, según se adelantó, de las discrepancias relativas a la posibilidad misma de reconocimiento de la indemnización en los supuestos de nulidades "objetivas" o "automáticas" de los despidos por aplicación del artículo 55.5 del ET.

A este respecto, existe un sector de la doctrina que defiende, en el ámbito del despido por causa de maternidad, la necesidad de conceder la indemnización del artículo 183.2 LRJS 
tanto en caso de despidos nulos discriminatorios propiamente dichos como en el caso de nulidades objetivas. Desde este punto de vista, la concesión de la indemnización vendría impuesta por el engarce constitucional y comunitario de este tipo de nulidades, cuyo fundamento no debe buscarse en la intención de discriminar, sino en la prohibición de realizar "prácticas obstaculizadoras injustificadas" del derecho a la igualdad de oportunidades entre los hombres y las mujeres, ex artículo 14 de la CE y 20 de la Carta de Derechos Fundamentales de la Unión Europea. Según esta interpretación, con independencia de que el artículo 55.5 ET sea una norma de mejora de la Directiva 92/85, al conceder la indemnización se daría cumplimiento a la exigencia de una tutela preventiva útil frente al despido de las trabajadoras madres que viene impuesta por la jurisprudencia comunitaria en sentencias como la de 11 de octubre de 2007, Paquay, C460/06 o la de 22 de febrero de 2018, Jessica Porras Guisado, C-103/16 ${ }^{35}$. En la última se afirma, ciertamente, que "habida cuenta del riesgo que supone para el estado físico y psíquico de las trabajadoras embarazadas, que hayan dado a luz o en período de lactancia la contingencia de un despido, la protección en concepto de reparación, aun cuando dé lugar a la readmisión de la trabajadora despedida y al abono de la retribución dejada de percibir a causa del despido, no puede sustituir a la protección de carácter preventivo", es decir, a la protección contra el despido en sí mismo, no contra sus consecuencias. Por ello se concluye que, "con el fin de garantizar tanto la fiel transposición del artículo 10 de la Directiva 92/85 como la protección de las trabajadoras embarazadas, que hayan dado a luz o en período de lactancia contra el riesgo de despido, los Estados miembros no pueden limitarse a establecer únicamente, en concepto de reparación, la nulidad de ese despido cuando no esté justificado".

En esta línea interpretativa, aunque anudando la protección conferida con la intención discriminatoria, es posible mencionar, por ejemplo, la STSJ del País Vasco de 12 de junio de 2018 (Rec. 1028/2018), que no duda en otorgar la indemnización al entender que el despido nulo por causa de embarazo responde a una tutela objetiva "tanto de la maternidad como de la discriminación por razón de sexo" y, de ahí, el que opere una protección reforzada a la trabajadora en esta situación, con independencia, de que exista conocimiento por parte del empleador de esta circunstancia.

Siguiendo la estela de la postura doctrinal descrita cabe encontrar en suplicación, además, pronunciamientos favorables a la concesión de la indemnización en otros supuestos de nulidad objetiva del despido, como la debida al hecho de encontrarse el trabajador en reducción de jornada. Así lo hace la STSJ de Andalucía (Sevilla) de 23 de enero de 2020 (Rec. 3399/2018), frente a la pretensión empresarial contraria a la indemnización adicional de 7.000 euros otorgada en la instancia por no conllevar el despido nulo objetivo una indemnización adicional automática: "El artículo 55.5 ET, norma de mejora de la

\footnotetext{
${ }^{35}$ MOLINA NAVARRETE, Cristóbal, "El "plus de riesgo de despido" de las mujeres embarazadas: ¿"indemnización disuasoria" también para la nulidad objetiva? Comentario a la Sentencia del Tribunal Supremo 942/2017, de 28 de noviembre, RTSS. CEF, 421, 2018, pp. 139 y 141.
} 
Directiva 92/1985, debe llevar a entender que la mera nulidad-readmisión-salarios de trámite no satisfacen los daños creados en tales despidos y por ello la respuesta resarcitoria ex art. 183.2 LRJS queda condicionada en su obligado y automático reconocimiento tanto por su dimensión constitucional y comunitaria -igualdad de oportunidades- como por la necesidad de una medida de mayor eficacia preventiva del riesgo de despido de los trabajadores/as que hayan solicitado o estén disfrutando de medidas de reducción de jornada o excedencia para la conciliación de la vida familiar y laboral. No es baladí recordar que el TJUE afirma que el art. 10.1 Directiva 92/85 se opone a toda orden jurídica nacional que establezca únicamente "la nulidad del despido" cuando sea ilegal, como medida única de reparación, obviando los aspectos preventivos.

En suma, estamos ante la figura de la nulidad de despido, en la modalidad reforzada u objetiva, con lo que hay una automaticidad del resarcimiento indemnizatorio por la función preventiva de la institución, de modo que se asocia la indemnización adicional a la nulidad objetiva de los despidos ex art. 55.5.b) ET. Cualquier otra comprensión de la figura de la nulidad de despido en la modalidad reforzada u objetiva la reduciría a mera tutela simbólica".

Hay que advertir, no obstante, que existen argumentos sólidos en contra de esta posición hermenéutica.

Por un lado, como recuerdan otros Tribunales de suplicación a la luz de la jurisprudencia constitucional (vid., entre otras, SSTSJ de Castilla-León (Valladolid), de 18 de noviembre de 2015, Rec. 2005/2015; STSJ de Cataluña de 26 de abril de 2018, Rec. 3002/2015; o SSTSJ de Galicia de 7 de noviembre de 2019, Rec. 4093/2019; y de 9 de diciembre de 2019, Rec. 3789/2019), en nuestro ordenamiento se dispensan dos grados de tutela por razón del embarazo: una objetiva y automática, distinta de la nulidad por causa de discriminación, y que supera los niveles mínimos de protección de la Directiva 92/85, que constituye una acción positiva basada en el embarazo mismo, con independencia de su conocimiento por el empresario; y otra antidiscriminatoria -consagrada en el artículo 55.5 primer párrafo del ET, artículo 8 Ley Orgánica 3/2007, de 22 de marzo, para la igualdad efectiva de mujeres y hombres, y artículo $14 \mathrm{CE}$ - que requiere la existencia de un acto de discriminación por razón de sexo perpetrado por el empresario. Puesto que la nulidad de los despidos que contempla el artículo 55.5 ET es una nulidad que surge, según ha reconocido también el propio Tribunal Supremo (SSTS de 25 de noviembre de 2014, Rec. 2344/2013, o de 18 de abril de 2017, Rec. 2771/2015, entre otras), al margen de que existan o no indicios de tratamiento discriminatorio o, incluso, de que concurra o no un móvil de discriminación, según este sector de la doctrina judicial, únicamente en la 
segunda situación, en cuanto vulneradora de derechos fundamentales, quedaría justificada la imposición de una indemnización ${ }^{36}$.

Así pues, no se pone en duda que siempre que la parte demandante denuncie algún tipo de vulneración de derechos fundamentales $-\mathrm{o}$ de discriminación, en su caso- y la sentencia así lo reconozca proceda la indemnización, lo que se dice es que procederá por aplicación de lo dispuesto en el primer párrafo del artículo 55.5 ET.

En realidad, el carácter objetivo, automático e independiente del conocimiento de la situación por parte del empresario en los casos de nulidades objetivas casa mal con la concesión de una indemnización como la del artículo 183.2 de la LRJS en la, sin duda alguna, se pondera la presencia de un factor de "culpa" o "animosidad" del ofensor tanto a la hora de determinar los daños morales como en el momento de cuantificar el elemento disuasorio $^{37}$. Y, por supuesto, casa mal con el concepto mismo de daños punitivos -si se admite que la indemnización los integra- reservados, incluso en los sistemas que los aceptan de manera generalizada, como ya se ha indicado, para casos de extraordinaria gravedad y de conducta especialmente intolerable del infractor.

Por otro lado, en cuanto a la exigencia comunitaria de tutela preventiva útil, cabe subrayar que su sentido, probablemente, es otro: el TJUE la exige frente al despido de las trabajadoras madres y en el contexto de la Directiva 92/85 -respecto a la que el artículo 55.5 ET es una mejora- en consideración al riesgo que un posible despido supone "para el estado físico y psíquico" de las trabajadoras embarazadas, que hayan dado a luz o en período de lactancia. De ahí que el Tribunal Superior de Justicia de Cataluña -tras plantear por auto de fecha 20 de enero de 2016 la cuestión prejudicial origen de la STJUE de 22 de febrero de 2018, Jessica Porras Guisado, C-103/2016- en su sentencia de 26 de abril de 2018, Rec. 3002/2015, al resolver sobre el fondo del asunto, haya situado el incumplimiento del Estado español al margen de las dos tutelas mencionadas antidiscriminatoria y objetiva- para conectarla con una tercera tutela: la efectuada por razón de riesgos laborales en el Derecho comunitario ("existe una tercera tutela por razón de riesgos laborales en el Derecho comunitario, que es la que aquí interesa y que no es ni antidiscriminatoria ni objetiva, sino que se trata del de una tutela de la mujer embarazada frente al despido, al que la Directiva 92/85 considera como un riesgo para su salud física y psíquica"). Enmarcado el artículo 10 de la Directiva 92/85 en el ámbito preventivo de riesgos laborales, el Tribunal considera que no existe en nuestro ordenamiento interno una transposición de la Directiva en tal contexto, pues tanto la tutela antidiscriminatoria frente al despido de la mujer embarazada como la tutela objetiva frente al despido son $e x$

\footnotetext{
36 También se han pronunciado en este sentido, recientemente, la sentencia del Juzgado de lo Social de Salamanca 395/2019, de 22 de noviembre, o la del Juzgado de lo Social de Valladolid 382/2019, de 8 de noviembre.

${ }^{37}$ Sobre la presencia de este factor en ambos casos, BALLESTER PASTOR, María Amparo, "El proceloso camino hacia la efectividad y adecuación de las indemnizaciones por vulneración de derechos fundamentales", Revista de Derecho Social, 69, 2015, p. 39
} 
post, pero en ningún momento se contempla la prohibición de despedir como riesgo para la salud de la embarazada (tutela ex ante).

Esta segunda postura interpretativa, en fin, puede "intuirse" de lo dispuesto en el auto del Tribunal Supremo de 10 de junio de 2018 (Rec. 3070/2017). Aunque el Tribunal rehúsa a entrar en el fondo del asunto, para justificar la falta de contradicción señala que, a diferencia del caso de autos, en el supuesto de contraste se debate si la empresa conocía o no su situación de embarazo y si ello es trascendente a efectos de la calificación del despido, datos "que lógicamente pueden incidir en la decisión de la sala de fijar o no la indemnización adicional por daños y perjuicios".

\section{Conclusiones}

El análisis del reconocimiento de la indemnización por vulneración de derechos fundamentales en el orden social de la jurisdicción permite localizar, tanto antes como después de la entrada en vigor de la actual regulación, sin excesiva dificultad, interpretaciones encontradas cuando de la determinación de la indemnización se trata.

En ciertos casos - como sucede con la automaticidad del daño moral derivado de la violación del derecho fundamental- las contradicciones y vaivenes judiciales son ya un "clásico" en la materia; en otros, las dudas guardan relación con el significado y la repercusión que una incorporación legal efectuada por la LRJS -la finalidad preventiva de la indemnización- debe tener en la práctica judicial; $y$, finalmente, las discrepancias se refieren a la posibilidad misma de concesión de la indemnización en determinadas situaciones -nulidades "objetivas" o "automáticas" de los despidos por aplicación del artículo 55.5 del Estatuto de los Trabajadores-.

Sin perjuicio de que sean muchas las dudas interpretativas que persisten el respecto, lo cierto es que el Tribunal Supremo ha tenido la oportunidad de pronunciarse, al menos en parte, en relación con las dos primeras cuestiones. En efecto, la jurisprudencia más reciente se ha decantado, por lo que al primer tema se refiere, por la existencia de una "unión indisoluble" entre los daños morales y la vulneración del derecho fundamental; y, por lo que a la finalidad preventiva de la indemnización respecta, sin entrar en la disquisición teórica sobre su carácter punitivo, ha resuelto cualquier duda que pudiera quedar al declarar que el artículo 183.2 LRJS viene a asignar a la indemnización no sólo una función resarcitoria (la utópica restitutio in integrum), sino también la de prevención general.

A partir de ahí, la dificultad estriba en la determinación judicial de ese importe indemnizatorio, pues debe ser suficiente, en consecuencia, para reparar el daño moral indisolublemente unido a la vulneración del derecho y, además, para contribuir a la finalidad de prevenir el daño. 
En relación con la suficiencia de la reparación del daño moral, es imprescindible subrayar que, aunque, finalmente, el Tribunal Supremo no haya descartado la automaticidad de la indemnización por daños morales, a pesar de precisar su reconocimiento la consideración de los factores concurrentes, eso no implica que dichos factores (gravedad de la conducta, duración, consecuencias del daño) no jueguen un papel esencial en la determinación prudencial de la indemnización. La imposibilidad de aplicar de manera automática la LISOS y la prohibición de la arbitrariedad hacen impensable, en realidad, cualquier otra solución tratándose de la fijación del importe de una indemnización no tasada, y así lo corroboran, según se ha analizado, sentencias recientes del propio Tribunal Supremo y los últimos pronunciamientos de los tribunales inferiores. No puede prescindirse, pues, de las circunstancias que rodean la vulneración del derecho, aunque, como indicara el Tribunal Constitucional en su sentencia 247/2006, no siempre sea exigible la prueba concreta del perjuicio sufrido y de su cuantificación monetaria.

Exactamente lo mismo sucederá en la apreciación judicial de la suficiencia de la indemnización desde el punto de vista de la finalidad preventiva. Por eso, quizá, más que el debate referente a la incorporación en el artículo 183 LRJS de la figura de los daños punitivos, resulta esencial la generalización de la consideración del cumplimiento de tal finalidad como una finalidad diferenciada de la resarcitoria, lleve o no tal consideración, dependiendo de los casos, al otorgamiento de una cantidad diferenciada con función preventiva.

El Tribunal Supremo todavía no ha tenido todavía la oportunidad de pronunciarse, sin embargo, acerca de la procedencia de la indemnización en caso de nulidad "objetiva" o "automática" del despido por aplicación del artículo 55.5 ET. A la espera de un pronunciamiento al respecto -la contradicción entre las sentencias dictadas por los Tribunales de suplicación es patente- cabría defender, por las razones expuestas, la contundencia de los argumentos contrarios a tal reconocimiento, al margen de que esa sea la postura que se puede "entrever" en el ya mencionado auto de 10 de junio de 2018 (Rec. 3070/2017).

\section{Bibliografía}

BALLESTER PASTOR, María Amparo, "El proceloso camino hacia la efectividad y adecuación de las indemnizaciones por vulneración de derechos fundamentales”, Revista de Derecho Social, 69, 2015, pp. 31-56.

BLASCO PELLICER, Ángel y LÓPEZ TERRADA, Eva, "Proceso de tutela de los derechos fundamentales y libertades públicas", en: BLASCO, Ángel; ALEGRE, Manuel (coords.), El proceso laboral: Ley 36/2011, de 10 de octubre, reguladora de la Jurisdicción Social, Valencia, Tirant lo Blanch, 2013, pp. 1093-1166. 
CARDENAL CARRO, Miguel, La indemnización en los procesos de tutela de la libertad sindical (Un estudio jurisprudencial del razonamiento acerca de su pertinencia), Pamplona, Thomson-Aranzadi, 2006.

CARRASCOSA GONZÁLEZ, Javier, "Daños punitivos. Aspectos de derecho internacional privado europeo y español", en: HERRADOR GUARDIA, Mariano José (dir.), Derecho de daños, 2013, p. 3. Recuperado de http://www.accursio.com/private/uploads/111_UMU_Punitive_Damages_by_J_Carrasc osa.pdf.

DÍEZ-PICAZO, Luis, El escándalo del daño moral, Cizur Menor, Thomson-Civitas, 2008.

GOERLICH PESET, José María, "La reparación de los daños morales derivados de lesión de un derecho fundamental por los tribunales del orden social: algunos pronunciamientos recientes del Tribunal Supremo", 2019. Recuperado de http://online.elderecho.com

LAHERA FORTEZA, Jesús, "Las acciones de indemnización de daños por vulneración de la libertad sindical tras la Ley 36/2011 de Jurisdicción Social”, Relaciones Laborales, 8, 2012, pp. 29-44.

LOUSADA AROCHENA, José Fernando, La tutela de los derechos fundamentales y de las libertades públicas en la Ley Reguladora de la Jurisdicción Social, Albacete, Bomarzo, 2012.

MANEIRO VÁZQUEZ, Yolanda, La tutela de los derechos fundamentales y libertades públicas por los tribunales laborales, La Coruña, Netbiblo, 2007.

MANEIRO VÁZQUEZ, Yolanda, "El derecho a la indemnización por daños morales como consecuencia de la lesión de la libertad sindical a la luz de la sentencia TC 247/2006, de 24 de julio", Dereito: revista xurídica da Universidade de Santiago de Compostela, Vol.22, nº ext.:245-263, 2013, pp. 245-263.

MOLINA NAVARRETE, Cristóbal, "El "plus de riesgo de despido" de las mujeres embarazadas: ¿"indemnización disuasoria” también para la nulidad objetiva? Comentario a la Sentencia del Tribunal Supremo 942/2017, de 28 de noviembre, RTSS. CEF, 421, 2018, pp. 134-142.

MOLINA NAVARRETE, Cristóbal, ¿La «indemnización disuasoria» deja de ser «retórica judicial» para cuantificarse de forma diferenciada (aún escasa)? Recuperado de: https://www.laboral-social.com/pionera-sentencia-tsj-pais-vasco-17-julio-2018da\%C3\%B1os-morales-fija-plus-indemnizatorio-disuasorio.html.

MOLINA NAVARRETE, Cristóbal, Indemnizaciones disuasorias, nueva garantía de efectividad de la tutela social: entre retórica judicial y prácticas innovadoras, Albacete, Bomarzo, 2019. 
MONTOYA MELGAR, Alfredo, et al., Curso de procedimiento laboral, Madrid, Tecnos, $9^{\mathrm{a}}$ ed., 2012.

PEDRAJAS MORENO, Abdón, Despido y derechos fundamentales. Estudio especial de la presunción de inocencia, Madrid, Trotta, 1992.

REGLERO CAMPOS, Luis Fernando, "Conceptos generales y elementos de delimitación”. En: Nuevos clásicos. Tratado de Responsabilidad Civil, Aranzadi, 2014.

SÁNCHEZ PÉREZ, José, "El proceso especial de tutela de los derechos fundamentales en la jurisdicción social y su vertiente reparadora", Derecho de las relaciones laborales, 9, 2016, pp. 873-884.

SÁNCHEZ PÉREZ, José, "La reparación del daño en la jurisdicción laboral”, Revista Española de Derecho del Trabajo, 216, 2019, pp. 1-29.

TEBALÁN PALACIOS, Herberth Isamar, "La reformulación de la indemnización por daños en el proceso especial de tutela de derechos fundamentales laborales", Trabajo y Derecho, 49, 2019, pp. 1-17. 